\title{
Obtaining Oligo- and Monosaccharides from Agroindustrial and Agricultural Residues Using Hydrothermal Treatments
}

\author{
Fiorella P. Cardenas-Toro, Sylvia C. Alcazar-Alay, Tânia Forster-Carneiro, M. Angela A. Meireles” \\ LASEFI/DEA/FEA (School of Food Engineering)/UNICAMP (University of Campinas), Rua Monteiro Lobato, 80; Campinas, \\ SP; CEP: 13083-862, Brazil
}

\begin{abstract}
Agricultural and agroindustrial residues are major sources of cellulose, hemicellulose, and starch that can be converted into bioactive compounds, such as oligosaccharides and monosaccharides, using various chemical and biological methods. These bioactive compounds can be used as raw materials by food, cosmetic and pharmaceutical industries, as well as in the production of intermediate products and the development of biomaterials by chemical industries. In Brazil, the major industrial residues, which are corn residues, soybean residues, sugarcane bagasse, palm and coconut fibers, and grape and tomato seeds, among others, are produced at a rate of approximately of 600 million tons per year. Thus, the utilization of these residues using sustainable technology is of great interest. Hydrothermal treatment is a green technology that includes autohydrolysis as well as subcritical and supercritical hydrolysis, in which water is used at high pressures and temperatures to recover polysaccharides from complex vegetal matrices. The hydrolytic mechanisms can be improved by changing the ionic product or the polarity and electrical conductivity of water in subcritical and supercritical states. These properties promote the selective dissolution of the starch, hemicellulose and cellulose in the residues. The conversion of starch and hemicellulose into oligosaccharides and monosaccharides is preferentially performed at temperatures of less than $200^{\circ} \mathrm{C}$. In contrast, the conversion of cellulose into oligosaccharides is promoted at temperatures greater than $200^{\circ} \mathrm{C}$, with the highest amount oligosaccharide formation occurring at close to the critical point. In this article, the main biomass components, the properties of water under subcritical and supercritical conditions, and the latest studies of polysaccharide conversion in biomasses using hydrothermal treatments are reviewed.
\end{abstract}

Keywords Monosaccharides, Oligosaccharides, Biomass, Subcritical water, Supercritical water, Hydrothermal treatment

\section{Introduction}

The continuous population increase and the rapid consumption of non-renewable resources in the world have promoted extensive research of sustainable alternatives that could help to preserve the ecosystem for future generations [1]. A lignocellulosic biomass is a complex vegetal matrix composed mainly of cellulose, hemicellulose, starch and lignin. It is one of the most abundant raw materials in earth and it can be converted into marketable products without competition with the food supply chain. Recently, studies of biomass transformation have focused on the recovery of carbohydrates from starch, hemicellulose and cellulose to produce oligosaccharides, monosaccharides and ethanol [2]. The depolymerization of hemicellulose and cellulose into

* Corresponding author:

maameireles@gmail.com (M. Angela A. Meireles)

Published online at http://journal.sapub.org/fph

Copyright (C) 2014 Scientific \& Academic Publishing. All Rights Reserved oligosaccharides, monosaccharides and their degradation products using conventional techniques, such as acid hydrolysis, alkaline hydrolysis and enzymatic hydrolysis, has been extensively studied [3]. However, these techniques present disadvantages in processing operations such as equipment corrosion, necessary neutralization steps and long reaction periods. In addition, the development of new economically feasible technologies for the production of target compounds with high yield and less pollution is required. Hydrothermal technologies are green technologies that are suitable for the recovery of valuable compounds from biomass in which water is used at high temperatures and pressures without the addition of catalysts. Among these technologies, autohydrolysis, subcritical hydrolysis and supercritical hydrolysis are the most studied techniques. Water at a high temperature and pressure acts as a reaction medium for chemical processing of biomass because of the change in its physicochemical properties compared to water under normal conditions. This change of properties includes a reduced dielectric constant which increases the solubility 
of organic compounds, an increased ionic product which promote acid-base reactions and a greater density which improves solubility. These conditions led water to be considered as a suitable solvent and reaction medium for the decomposition of biomass. Several studies using model compounds composed of starch, hemicellulose and cellulose have shown that the use of water at mild temperature conditions (less than $200^{\circ} \mathrm{C}$ ) led to the complete degradation of starch and hemicellulose into oligosaccharides, whereas supercritical water promoted the complete depolymerization of cellulose during short residence periods.

In this paper, a review of the state of the art of hydrolysis of the cellulose, hemicellulose and starch present in agricultural and agroindustrial biomasses is presented, aimed at a better understanding of the operational conditions that promote the formation of oligosaccharides and monosaccharides.

\section{Biomasses}

The production of plant biomasses, which are typically the non-food parts of plants, is based on the photosynthetic process, during which polymeric carbohydrates with a ratio of $\left[\mathrm{CH}_{1.4} \mathrm{O}_{0.6}\right]_{\mathrm{n}}$ are generated. The chemical components of biomass are cellulose, hemicellulose, starch, lignin, ash and small amounts of extractable compounds, such as lipids and proteins. The main sources of lignocellulosic biomass can be classified as follows: forest residues; agricultural and agro-industrial residues; energy crops; municipal solid waste and organic industrial waste [3]. Cellulose, hemicellulose and starch are macromolecules composed of different types of sugars, whereas lignin is an aromatic polymer synthesized from phenylpropanoid precursors. Additionally, these components, including oligosaccharides, pectins, gums and waxes, are elements of dietary fiber, which is recognized for its health benefits and is included in the processing of fiber-rich products by food industry [4]. Table 1 shows the relative amounts of cellulose, hemicellulose, starch and lignin in various agricultural and agro-industrial lignocellulosic residues.

\subsection{Major Polysaccharide Components of Biomasses}

\subsubsection{Cellulose}

Cellulose is the most abundant biopolymer in nature. It is a linear homopolymer of $\beta$-(1 $\rightarrow 4)$-D-glucopyranose with a high degree of polymerization (DP), of between 200 and 12,000 . These DP values depend on the origin of the cellulose and the pretreatment of the biomass and affect its properties. Cellobiose is the basic structural unit of cellulose, consisting of two units of 4-O- $\beta$-D-glucopyranosyl $-\beta$-D-glucopyranose. Figure 1 shows the chemical structure of cellulose in a chair conformation (the most common conformation for cellulose). The C-2, C-3 and C-6 of each glucopyranose unit are linked to hydroxyl groups that undergo the characteristic reactions of primary and secondary alcohols. Moreover, the hydroxyl groups that are linked to C-1 and C-4 at the end of cellulose chain are the most reactive groups for intra- and intermolecular iterations and degradative reactions because they have reducing and non-reducing properties, respectively [5].

Cellulose constitutes up to $30 \%$ of the primary cell wall and 40 to $90 \%$ of the secondary cell wall [6], [7]. The basic units of cellulose are linked by intermolecular hydrogen bonds to form microfibrils with a diameter of between 3-25 $\mathrm{nm}$ [8], [9]. The strong hydrogen bonding between the cellulose units is mainly due to the close interaction between the hydroxyl groups in the equatorial orientation and hydrogen atom in the axial orientation, which results in high crystallinity and low solubility in aqueous media (8-14\% solubility in water under normal conditions). Moreover, the microfibrils represent amorphous regions (15-20\%) that are more vulnerable to chemical and enzymatic attack than are the crystalline regions [10]. Cellulose is not digested by human gastrointestinal enzymes and it has been used as a bulking additive in food manufacturing due to its water-absorbing ability and low solubility [4], [11], [12].

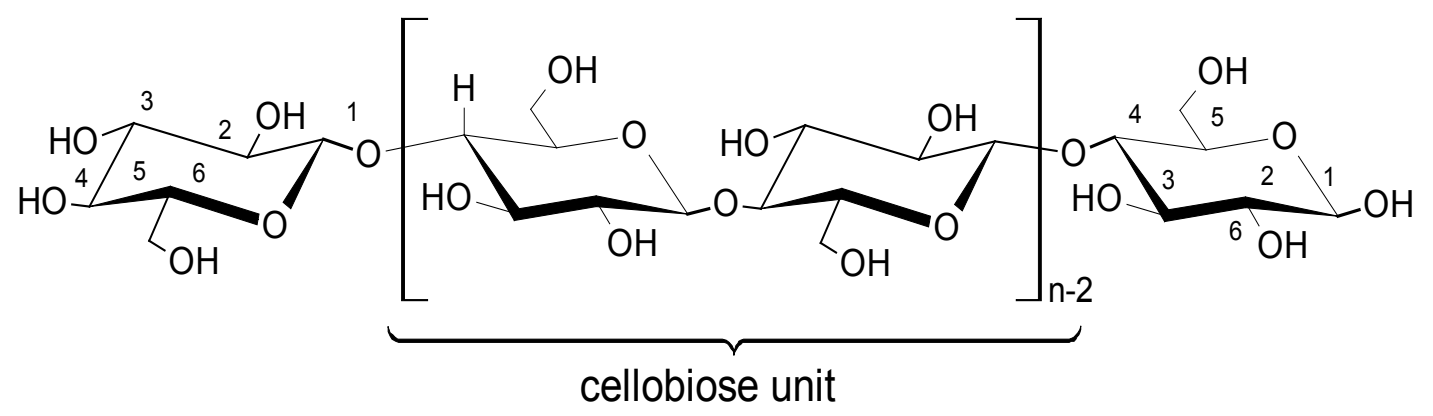

Figure 1. Molecular structure of cellulose (adapted from Klemm et al. [5]) 


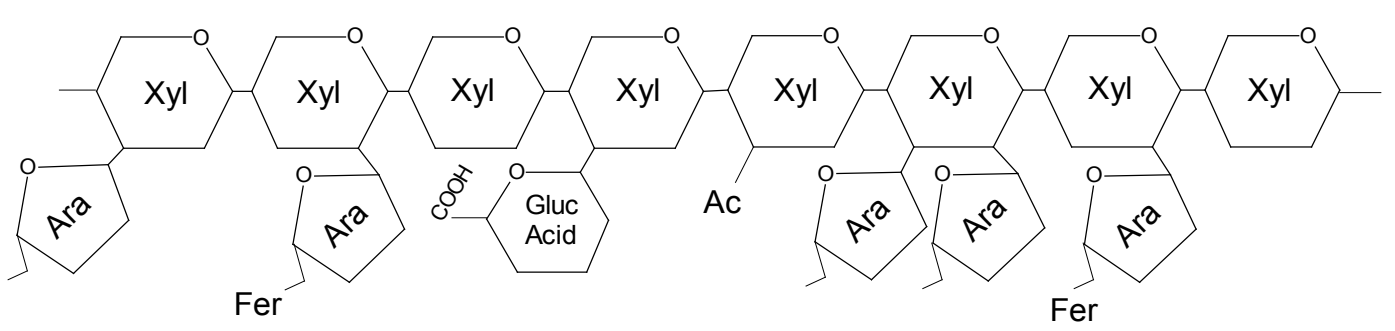

a)

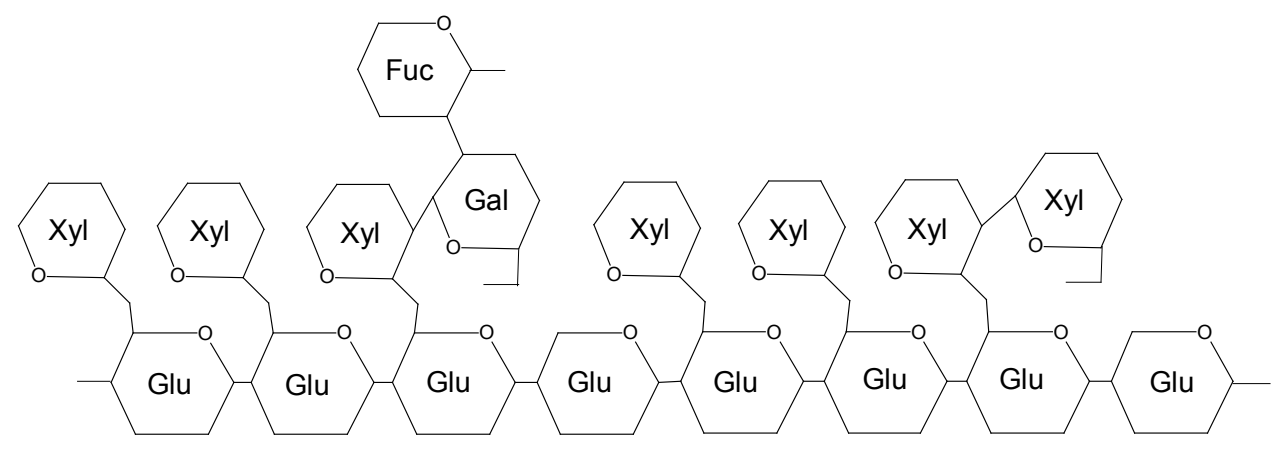

b)

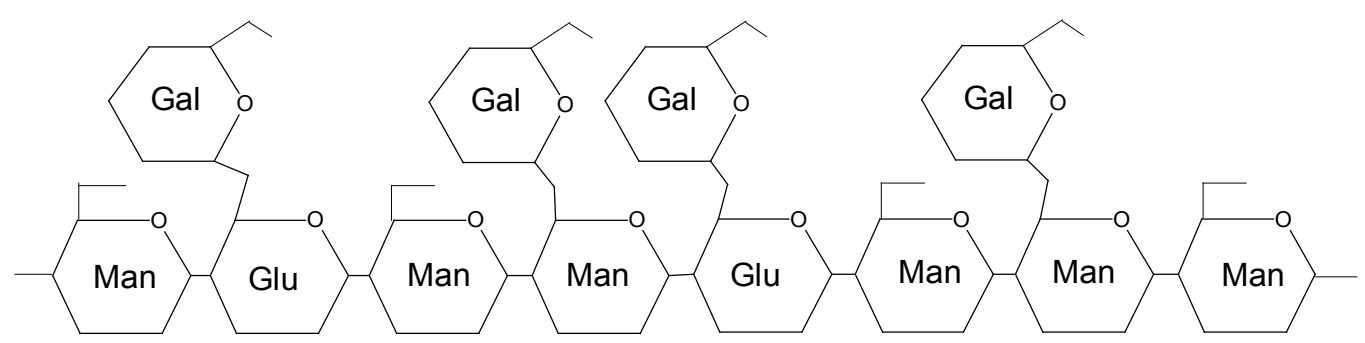

c)

Figure 2. Schematic representation of the main types of hemicellulose in plants: a) glucuronoarabinoxylan, b) xyloglucan and c) galactoglucomannan (adapted from Scheller and Ulvskov [13]

\subsubsection{Hemicellulose}

Hemicellulose is a heterogeneous branched polymer with a backbone composed of glucose, mannose and xylose joined by $\beta-(1 \rightarrow 4)$ linkages in an equatorial configuration, and in some cases, linkages with uronic acid. Hemicellulose has structural and physic-chemical properties that are different from those of cellulose, pectin and starch. There are several classes of hemicelluloses, such as xylans, xyloglucans, mannans, glucomannans, arabinoxylans, glucoroarabinoxylans, 4-O-methyl-glucuronoxylans and $\beta-(1 \rightarrow 3,1 \rightarrow 4)$-glucans, as shown in Figure 2. In general, their structures resemble a long rod with branches and side chains linked by hydrogen bonds, and they have lower molecular weights than cellulose. In addition, hemicelluloses comprise a soluble fraction and an insoluble fraction, which can be degraded by intestinal microflora [13].

Hemicelluloses have many applications in the food industry, for example, seeds such as guar gum (galactomannans) and tamarind gum (xyloglucan) are used directly in products as bulking agents. $\beta-(1 \rightarrow 3,1 \rightarrow 4)$ glucans, a major component of barley and oat cells, contributes to the reduction of serum cholesterol concentrations. This compound is used in cereal products as soluble dietary fiber, and a daily intake of this hemicellulose has been recommended by the Food and Drug Administration [11], [13], [46], [47].

The hydrolysis of xylan to yield xylooligosaccharides (non-digestible oligosaccharides) using acid and enzymatic hydrolysis has been proposed to produce new prebiotics and soluble fibers. Xylooligosaccharides are used as dietary sweeteners and for food for diabetics [48].

\subsubsection{Starch}

Starch is one of the most abundant carbohydrates that is synthetized by plants and it can be found in roots, cereals and fruits. The most important sources of commercial starch are corn, potatoes, wheat, rice, cassava (tapioca) and sorghum, which provide the major energy sources in human and animal diets. Additionally, starch is the second major component of biomass, after cellulose. Starch is mainly composed of two homopolymers of glucose: amylose and amylopectin. Generally, normal starch (cereal starches) consists of $25 \%$ amylose and $75 \%$ amylopectin, waxy starches (maize, rice, and sorghum) consist of $0-8 \%$ amylose and high-amylose starches (maize and barley) consist of 
40-70\% amylose [11], [49], [50]. Furthermore, in nutritional terms, starch can be divided into the three following categories: rapidly digestible starch (RDS), slowly digestible starch (SDS) and RS (resistant starch). RDS is starch that is rapidly and completely digested in the small intestine, tends to be rapidly degraded to glucose and has a high glycemic index. SDS is starch that is digested in the small intestine at a lower rate than RDS. RS is the starch that is fermented in the large intestine by the gut microflora. This classification helps to predict the glycemic response to foods. Numerous physiological effects have been attributed to resistant starch, leading to its use as a dietary fiber and as a prebiotic ingredient, and include its contribution to preventing colon cancer and its hypoglycemic effect [51-53].

Table 1. Composition of agricultural and agroindustrial residues ( $\%$ dry basis)

\begin{tabular}{|c|c|c|c|c|c|c|c|c|c|c|c|}
\hline Biomass & Country & Cellulose & $\begin{array}{c}\text { Hemi- } \\
\text { cellulose }\end{array}$ & Starch & Pectin & $\begin{array}{l}\text { Carbo- } \\
\text { hydrate }\end{array}$ & $\begin{array}{c}\text { Soluble } \\
\text { sugars }\end{array}$ & Lignin & Protein & Ash & Ref. \\
\hline $\begin{array}{l}\text { Silver bird Betula } \\
\text { pendula }\end{array}$ & Finland & $43.1^{\mathrm{a}}$ & $20.9^{b}$ & - & - & - & 2.6 & 8.2 & - & - & {$[14]$} \\
\hline $\begin{array}{l}\text { Hardwood pine } \\
\text { chips }\end{array}$ & $\begin{array}{l}\text { United } \\
\text { States }\end{array}$ & $40.0^{\mathrm{a}}$ & $17.0^{\mathrm{b}}$ & - & - & - & - & 31.0 & - & 2 & {$[15]$} \\
\hline $\begin{array}{c}\text { Japanese beech } \\
\text { Fagus crenata } \\
\text { Sugi wood }\end{array}$ & Japan & 45.0 & 29.0 & - & - & - & - & 26.7 & - & - & {$[16]$} \\
\hline $\begin{array}{l}\text { Cryptomeria } \\
\text { japonica }\end{array}$ & Japan & 43.0 & 23.0 & - & - & - & - & 32.0 & - & - & [17] \\
\hline $\begin{array}{c}\text { Fern fronds Pteris } \\
\text { vittatal }\end{array}$ & France & 34.0 & 34.0 & - & - & - & - & 35.0 & - & - & {$[18]$} \\
\hline $\begin{array}{c}\text { Switchgrass } \\
\text { (Panicum virgatum) }\end{array}$ & $\begin{array}{l}\text { United } \\
\text { States }\end{array}$ & $42.9^{\mathrm{a}}$ & $23.5^{\mathrm{b}}$ & - & - & - & - & 21.8 & - & 2.4 & [19] \\
\hline Beech wood & Turkey & 45.1 & 31.5 & - & - & - & - & 22.3 & & & {$[20]$} \\
\hline $\begin{array}{c}\text { Eucalyptus globulus } \\
\text { wood }\end{array}$ & Spain & 46.3 & 20.7 & - & - & - & - & 22.9 & - & - & [21] \\
\hline Rapeseed straw & Poland & 49.2 & 14.6 & - & - & - & - & 21.6 & - & - & {$[22]$} \\
\hline Corn stalks & China & 17.7 & 30.7 & - & - & - & 29.0 & 8.5 & - & 5.1 & {$[23]$} \\
\hline Corn stalks & China & 22.8 & 43.0 & - & - & - & - & 15.6 & - & - & {$[24]$} \\
\hline Corn cobs & Spain & 36.8 & 30 & - & - & - & - & 23.1 & - & 1.0 & {$[25]$} \\
\hline Corn cobs & Spain & 34.3 & 31.1 & - & - & - & - & 18.8 & 3.3 & 1.3 & {$[26]$} \\
\hline Corn stover & $\begin{array}{l}\text { United } \\
\text { States }\end{array}$ & 34.5 & 27.7 & - & - & - & - & 17.8 & - & 5.6 & {$[27]$} \\
\hline Rice husks & Spain & $34.0^{\mathrm{a}}$ & $15.9^{\mathrm{b}}$ & - & - & - & - & 23.3 & 2.5 & 11.2 & {$[28]$} \\
\hline Rice husks & China & 25.4 & 49.6 & - & - & - & - & 22.8 & - & 17.0 & [29] \\
\hline Defatted rice bran & Japan & - & - & - & - & 54.6 & - & 11.1 & 19.3 & 13.6 & {$[30]$} \\
\hline Maize straw & China & 25.5 & 30.3 & - & - & - & - & 18.3 & - & 3.6 & [29] \\
\hline Rye straw & Germany & $43.6^{\mathrm{a}}$ & $20.0^{\mathrm{b}}$ & - & - & - & - & 22.0 & - & - & {$[31]$} \\
\hline Wheat straw & China & 23.5 & 12.6 & - & - & - & - & 36.1 & - & 9.9 & {$[23]$} \\
\hline Wheat bran & China & 38.6 & 21.5 & - & - & - & - & 23.8 & - & 4.1 & [29] \\
\hline Wheat husks & India & 36.0 & 18.0 & - & - & - & - & 16.0 & - & - & {$[32]$} \\
\hline Babassu flour & Brazil & 13.5 & 8.0 & 60.1 & - & - & - & 15.8 & 3.0 & - & {$[33]$} \\
\hline Sugarcane bagasse & Japan & 36.4 & 37.2 & - & - & - & - & 16.8 & - & - & [34] \\
\hline $\begin{array}{c}\text { Water lettuce } \\
\text { biomass }\end{array}$ & China & 53.0 & 15.0 & - & - & - & - & 6.0 & 14.0 & 2.3 & {$[35]$} \\
\hline $\begin{array}{l}\text { Ginger bagasse after } \\
\mathrm{CO}_{2} \text { extraction }\end{array}$ & Brazil & - & - & 56.5 & - & - & 6.1 & - & 12.0 & 5 & {$[36]$} \\
\hline $\begin{array}{l}\text { Citrus junos peels } \\
\text { after } \mathrm{CO}_{2} \text { extraction }\end{array}$ & Japan & 29.0 & 11.7 & - & 32.2 & - & - & - & - & - & {$[37]$} \\
\hline Cassava flour waste & Thailand & 16.0 & 5.0 & 60.0 & - & - & - & 19.0 & - & - & {$[38]$} \\
\hline Cassava pulp & Indonesia & - & - & 79.5 & - & - & - & - & 5.4 & 0.7 & [39] \\
\hline $\begin{array}{c}\text { Brewer's spent } \\
\text { grain }\end{array}$ & Portugal & - & - & - & - & 50 & - & - & 30 & 5 & {$[40]$} \\
\hline Almond shells & Spain & 26.8 & 32.5 & - & - & - & - & 27.4 & - & 2.8 & {$[41]$} \\
\hline Oil palm fronds & Malaysia & 44 & 30 & - & - & - & - & 15.4 & - & 3.2 & {$[42]$} \\
\hline Empty fruit bunches & Korea & 28.7 & 27.4 & - & - & - & - & 26.5 & - & 3.1 & {$[43]$} \\
\hline Oil palm shells & Malaysia & 39.7 & 21.8 & - & - & - & - & 32.5 & - & - & {$[44]$} \\
\hline Pressed palm fibers & Brazil & - & - & - & - & 48.6 & - & 32.1 & 6.3 & 3.1 & {$[45]$} \\
\hline
\end{tabular}

Reported as: ${ }^{\mathrm{a}}$ glucose, ${ }^{\mathrm{b}}$ xylose,${ }^{\mathrm{c}}$ nitrogen-free soluble substance, ${ }^{\mathrm{d}}$ crude fiber 
Figure 3 shows schematic representations of amylose and amylopectin. Amylose is defined as a linear polymer of between 500 and 6000 units of $\alpha$-(1,4)-D-glucopyranose with minor branches of a few molecules via $\alpha-(1,6)$ linkages [54]. The $\alpha$ - $(1,4)$-glycosidic bonds confer a random helical conformation of the molecule, in which the hydroxyl and hydrocarbon groups of anhydroglucose units are joined to form helices with parallel or antiparallel orientations. Analysis of the structure of amylose using X-ray diffraction revealed the presence of starch types A and B. These types are based on the hexagonal and antiparallel orientation of helical molecules, where in which type $\mathrm{A}$ is a helical molecule with eight molecules of water in the central region and type $\mathrm{B}$ has 36 water molecules in the central region. Amylopectin is a branched polymer with chains of $\alpha$-(1,4)-D-glucopyranose connected by $\alpha$-(1,6)-Dglucopyranose linkages. Amylopectin has a higher molecular weight than amylose and consists of between hundreds of thousands to tens of millions of anhydroglucose units. Chains of 15 to 20 units of glucose between the branching points are arranged in clusters, and they are linked by longer chains into several clusters. This polymodal distribution results in a starch granule having crystalline and amorphous regions [52], [55-57].

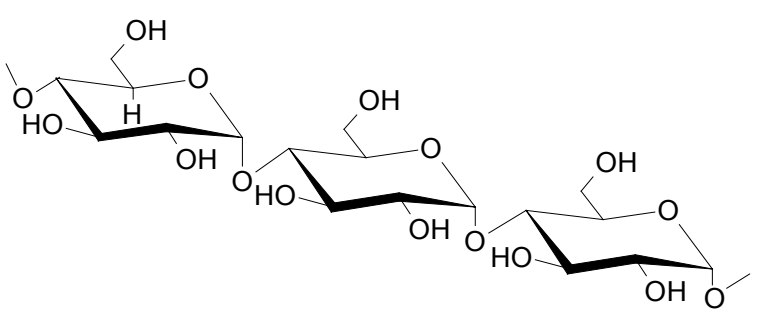

a)

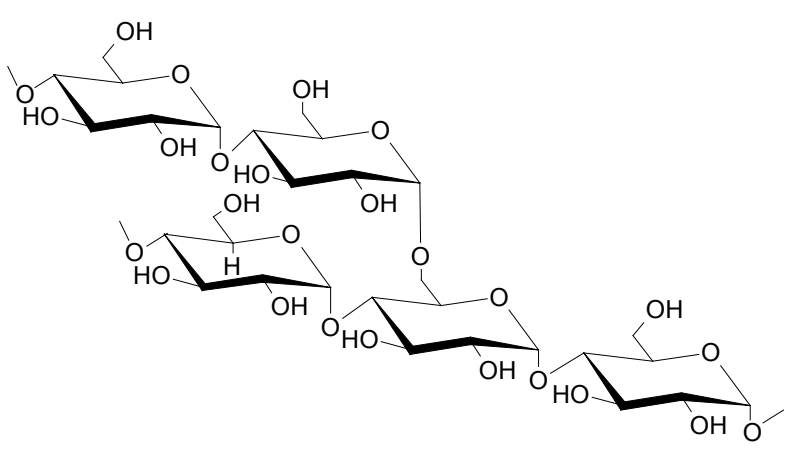

b)

Figure 3. Schematic representation of the basic unit of a) amylose and b) amylopectin in starch (adapted from [57])

Acid hydrolysis of starch causes fragmentation of its chains, with the subsequent formation of oligosaccharides and monosaccharides of glucose. Due to its $\alpha$-linkages, starch is easier to hydrolyze than are cellulose and hemicellulose [58]. Heating aqueous suspensions of starch granules causes them to swell, leading to disorganization of their structures, which is characterized by the loss of their birefringence, and the leaching of amylose and a portion of amylopectin, producing a viscous suspension (gelatinization). In addition, cooling this suspension promotes the realignment of linear chains of amylopectin in a process called retro gradation. Gelatinization improves the enzymatic hydrolysis of starch [11]. Commercial starches, mainly those from maize, tapioca, the potato and waxy maize, are chemically modified to improve their functional properties (viscosity, shelf stability, processing parameters, textures, appearance and emulsifiability). Enzymatic hydrolysis of starch produces non-digestible oligosaccharid es, such as maltooligosaccharide, isomaltooligosaccharide, and cyclodextrin, which are used as low-calorie sweeteners by the food industry [59].

\subsection{Biomasses in Brazil}

Agricultural and agroindustrial residues are obtained mainly from industrial and commercial enterprises, and they are considered potential raw materials for the production of value-added chemicals. In Brazil, the soybean, corn, wheat, rice, cotton, cassava, citrus, coconut and forestry industries generate approximately 600 million tons of waste per year. Therefore, new solutions for their utilization must be proposed. Table 2 shows the current availability of the main agricultural and agroindustrial residues [60], [61].

Table 2. Availability of agricultural and agroindustrial residues in Brazil [60], [61]

\begin{tabular}{|c|c|c|}
\hline Residue & $\begin{array}{c}1000 \\
t_{\text {DM }} / \text { year }\end{array}$ & Regional availability \\
\hline $\begin{array}{l}\text { Soybean waste (stalks, } \\
\text { leaves) }\end{array}$ & 118029 & Midwest, Southeast \\
\hline Corn waste (stalks, leaves) & 31007 & $\begin{array}{l}\text { South, Southeast, } \\
\text { Midwest }\end{array}$ \\
\hline Rice straw & 14102 & South, Midwest \\
\hline Forest residue & 14511 & North, South, Southeast \\
\hline Corn cobs & 10442 & $\begin{array}{l}\text { South, Southeast, } \\
\text { Midwest }\end{array}$ \\
\hline $\begin{array}{l}\text { Citrus waste (bagasse, husks } \\
\text { and seeds) }\end{array}$ & 10384 & n.s. \\
\hline Cotton stalks & 8561 & Midwest \\
\hline Sugarcane bagasse & 6400 & $\begin{array}{c}\text { Southeast, Midwest, } \\
\text { Northeast }\end{array}$ \\
\hline Wheat straw & 4966 & $\begin{array}{l}\text { South, Southeast, } \\
\text { Midwest }\end{array}$ \\
\hline Cassava bagasse & 4214 & n.s. \\
\hline Sawdust & 3950 & Southeast, South \\
\hline Sorghum leaves & 1922 & Southeast, Midwest \\
\hline Rice husks & 1772 & South, Southeast \\
\hline Coconut husks & 452 & $\begin{array}{l}\text { North, Northeast, } \\
\text { Southeast }\end{array}$ \\
\hline Palm fibers & 123 & North, Northeast \\
\hline Almond shells & 71 & $\begin{array}{c}\text { Southeast, Midwest, } \\
\text { Northeast }\end{array}$ \\
\hline Sawdust & 3950 & Southeast, South \\
\hline
\end{tabular}

$t_{\mathrm{DM}}$ : ton of dry matter; n.s.: not specified

The residues obtained after sugarcane processing consist of leaves and immature plants, which are considered potential raw materials for second-generation ethanol production. In contrast, the residues of corn crops and those 
generated by corn industries are mainly used as cattle feed. The residues generated by the palm-oil industry contain oils rich in alpha- and beta-carotenes, which are precursors of vitamin A, and have a high carbohydrate content. The extraction of palm fibers produces an oil rich in carotenoids, and the further conversion of its carbohydrate fraction into oligosaccharides and monosaccharides is a sustainable use of this residue [45], [62]. The residues generated by extracting antioxidant compounds from Brazilian ginseng roots contain high quantities of starch and cellulose. These residues can be used in hydrolytic reactions for saccharide production [63].

\section{Chemical Conversion of Biomasses}

Many technologies have been developed for the transformation of biomasses into valuable products for the food, pharmaceutical and chemical industries. In general, the chemical conversion of a biomass has been classified into three main categories, as follows: biochemical, mechanical and thermochemical conversion processes. The biochemical processes includes anaerobic digestion, saccharification and fermentation. Anaerobic digestion converts solid and liquid biomass into a mixture of methane and $\mathrm{CO}_{2}$ in the absence of $\mathrm{O}_{2}$. Saccharification and fermentation is a process that consists of the enzymatic hydrolysis of the cellulosic fraction into fermentable sugars under the mild conditions of $45-50^{\circ} \mathrm{C}$ and their subsequent fermentation by yeast at $37^{\circ} \mathrm{C}$ to yield ethanol. The mechanical processes are mechanical extractions of biomass seeds, such as canola, palm, sunflower and cotton seeds, to produce oil, which is further converted into biodiesel. Several sources have been employed to produce biodiesel, such as canola oil, palm oil, sunflower oil, soybean oil and recycled oil by mechanical processes. The thermochemical conversion processes include combustion, pyrolysis, gasification, liquefaction and chemical hydrolysis. Combustion processes are employed to produce electrical and thermal energy through burning the chemical energy stored in a biomass at temperatures of approximately $800-1000^{\circ} \mathrm{C}$. Pyrolysis converts a biomass into liquid (bio-oil), coal and non-condensable gases by heating it at a temperature higher than $400^{\circ} \mathrm{C}$ and a pressure of between 0.1 and $0.5 \mathrm{MPa}$ in the absence of air. Gasification is the partial oxidation of compounds at a high temperature, between 800 and $900^{\circ} \mathrm{C}$ that enhances the production of a combustible gas mixture of $\mathrm{CO}, \mathrm{H}_{2}, \mathrm{CH}_{4}$, $\mathrm{CO}_{2}$ and $\mathrm{N}_{2}$. Liquefaction uses water temperatures of between 250 and $350^{\circ} \mathrm{C}$ and pressures of between 5 and 20 MPa to produce gases and aqueous and oily products. Chemical hydrolysis consists of the cleavage of the polymeric bonds of a biomass using acids, bases or water (hydrothermal treatment) to yield oligosaccharides with various degrees of polymerization, monosaccharides and platform molecules, such as lactic acid, glycerol and levulinic acid [64-68].

\section{Hydrothermal Treatment of Cellulose, Hemicellulose and Starch in Biomasses}

Hydrothermal treatment is a process in which water at a high temperature and pressure is used to catalyze hydrolytic reactions. Water is one of the most useful green solvents in the chemical industry due to its non-toxicity, non-flammability, and wide availability in nature. This type of process entails autohydrolysis, hydrothermolysis, aqueous liquefaction, liquid hot-water pretreatment, subcritical water hydrolysis and supercritical water hydrolysis. These processes use water at temperatures and pressures higher than $100^{\circ} \mathrm{C}$ and $0.1 \mathrm{MPa}$, respectively, which are classified as subcritical and supercritical water hydrolysis [15],[69-71]. In the hydrothermal conversion of polysaccharides, subcritical or supercritical water is used to produce insoluble oligosaccharides, oligosaccharides (DP $<10$ ), monosaccha rides, such as glucose, fructose and xylose, and polyols, such as xylitol and sorbitol. In addition, degradation products, such as phenolic and furan derivatives, which are toxic to humans and microorganisms, are formed [72]. Therefore, optimization of the hydrolytic process in terms of the monomers and oligomers yielded has been studied by several researchers for its use in the food and chemical industries [73]. In general, hydrolysis of a biomass using subcritical water (temperatures of $150^{\circ} \mathrm{C}<\mathrm{T}<374^{\circ} \mathrm{C}$ and pressures of $\mathrm{P}>$ Psat) for a few minutes causes the depolymerization of hemicellulose and starch, the partial depolymerization of cellulose and the improved susceptibility of the crystalline cellulose fraction to subsequent hydrolysis [36], [74]. Supercritical hydrolysis of a biomass $\left(\mathrm{T}>374^{\circ} \mathrm{C}, \mathrm{P}>22.1\right.$ $\mathrm{MPa}$ ) causes the depolymerization of the crystalline cellulose and the separation of the hydrolytic products of lignin [73]. Hydrothermal treatments have advantages over other conventional treatments, such as acidic and enzymatic hydrolysis, because the mild $\mathrm{pH}$ conditions result in fewer problems due to corrosion compared to acidic hydrolysis, the steps for the waste management and recycling acid are avoided, and the reaction conditions provide excellent selectivity with respect to the degradation of polysaccharides, resulting in a simpler procedure.

\subsection{Physicochemical Properties of Water under Subcritical and Supercritical Conditions}

Subcritical water, which is also called superheated water or pressurized hot water, is defined as water with a temperature of between $100^{\circ} \mathrm{C}$ and $374^{\circ} \mathrm{C}$ (critical temperature) and a pressure higher than that of its vapor saturate, up to $22.1 \mathrm{MPa}$, to maintain the water in its liquid state. Supercritical water is a fluid with a temperature and pressure higher than those at its critical point $\left(374^{\circ} \mathrm{C}, 22.1\right.$ $\mathrm{MPa}$ ) [75]. Figure 4 shows the subcritical and supercritical regions of water [76]. The physicochemical properties of subcritical and supercritical water, such as the density, viscosity, dielectric constant and ionic product, vary 
considerably with the increase of temperature and pressure compared with the properties under normal conditions (Figure 5).

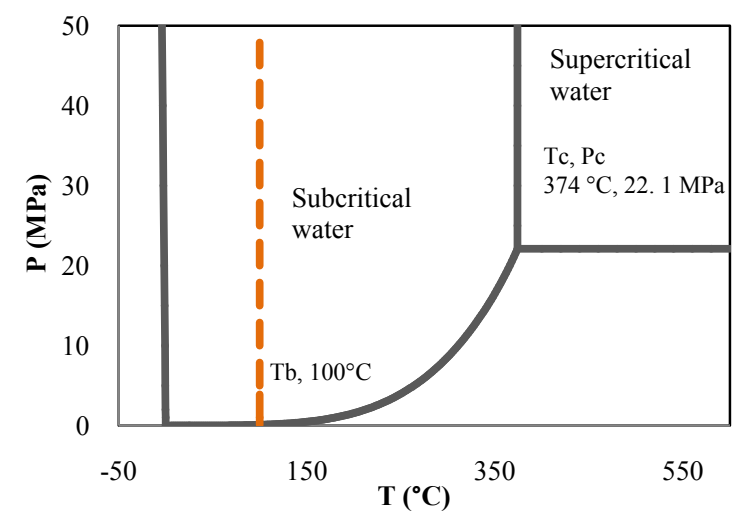

Figure 4. Pressure-temperature phase diagram of water: $\mathrm{Tc}=374^{\circ} \mathrm{C}$ (critical temperature), $\mathrm{Pc}=22.1 \mathrm{MPa}$ (critical pressure), $\mathrm{Tb}=100^{\circ} \mathrm{C}$ (boiling point). (data extracted from [76])

The physicochemical properties of water depend strongly upon its temperature; for example; ionization of hydrogen bonds at high temperatures causes a decrease in the dielectric constant from 35 at $200^{\circ} \mathrm{C}$ to 10 at the critical temperature of $374^{\circ} \mathrm{C}$. This feature makes water in subcritical and supercritical states suitable for organic reactions and the miscibility of organic compounds increases with temperature. Moreover, the content of the ionic product $\left(\mathrm{Kw}=\left[\mathrm{H}^{+}\right]\left[\mathrm{OH}^{-}\right]\right)$ of water is three orders of magnitude higher under these conditions than its value under normal conditions, so that it acts as acid-base catalyst. In addition, water's density decreases with the increase in temperature, from $1000 \mathrm{~kg} / \mathrm{m}^{3}$ at $25^{\circ} \mathrm{C}$ to $820 \mathrm{~kg} / \mathrm{m}^{3}$ at $250^{\circ} \mathrm{C}$ and $25 \mathrm{MPa}$. The combination of these phenomena causes the dependence of solvation power on temperature, in which high temperatures, near the supercritical point, lead to a high level of water dissociation and reduced density. These variations affect the kinetics of chemical reactions and the selectivity of a reaction within a network of reactions, and in many cases are considered catalytic [77], [78].

\subsection{Hydrothermal Treatment of Lignocellulosic Biomasses}

Different types of lignocellulosic biomasses were proposed as raw materials for the recovery of value-added compounds. This selection was based mainly on their abundance in the geographic region of study and their availability for conversion into value-added products. Treating a biomass with subcritical water at mild temperatures simultaneously catalyzes a number of chemical reactions, such as the progressive degradation of polysaccharides into xylooligomers, xylose monomers and degradation compounds (such as acetic acid and organic acids that decrease the $\mathrm{pH}$ of the medium). Higher temperatures and reaction periods promote the fragmentation of oligomers into monomers until a maximal monomer concentration is reached, and the formation of dehydration products such as furfural. The acidic medium promotes the partial solubilization of the soluble lignin without considerable modification of the insoluble cellulose and lignin. The depolymerization behavior of hemicellulose at temperatures below $200^{\circ} \mathrm{C}$ has allowed investigation into separating it from the other structural components of the biomass, such as cellulose and lignin [28]. Tables 3 and 4 show the results of experimental studies of subcritical and supercritical hydrolysis of model compounds (cellulose, hemicellulose, and starch) and agricultural and agricultural residues, respectively.
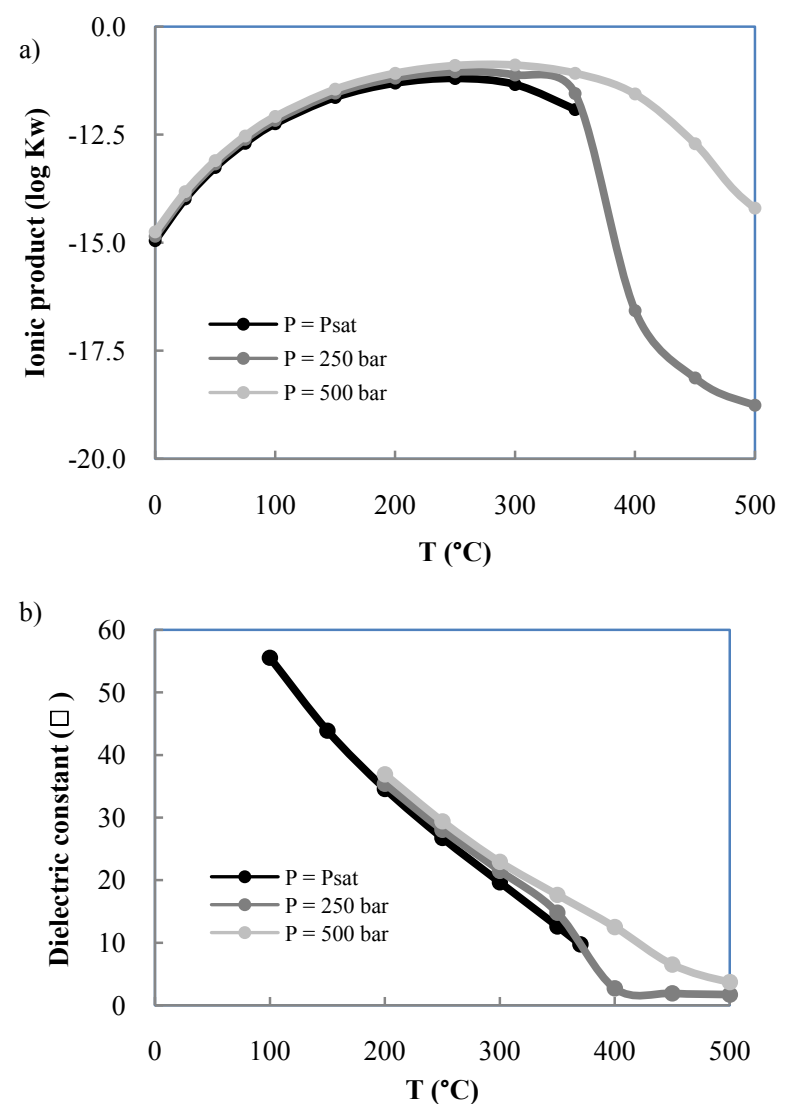

c)

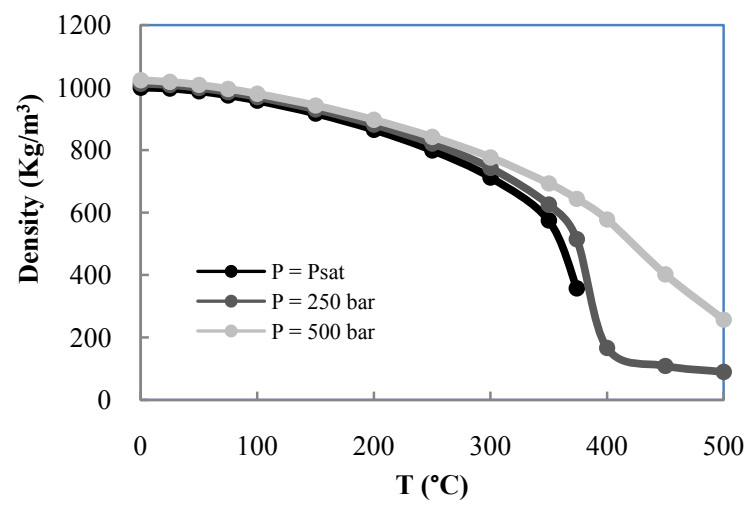

Figure 5. Physicochemical properties of water under subcritical and supercritical conditions (data extracted from [76],[79],[80]) 


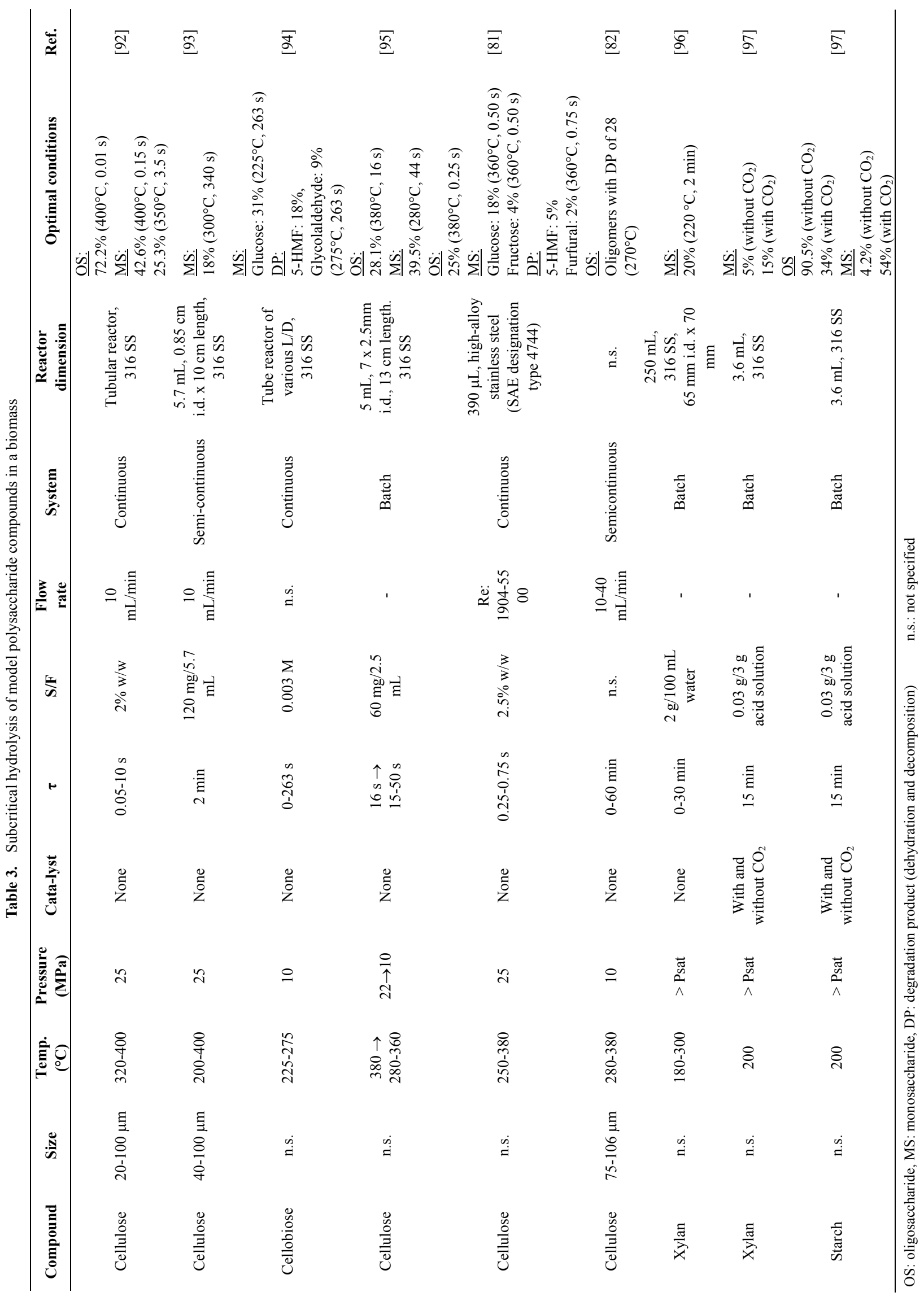


Table 4. Subcritical hydrolysis of agricultural and agroindustrial residues

\begin{tabular}{|c|c|c|c|c|c|c|c|c|c|c|}
\hline Biomass & Size & $\begin{array}{l}\text { Temp. } \\
\left({ }^{\circ} \mathrm{C}\right)\end{array}$ & $\begin{array}{c}\text { Pressure } \\
\text { (MPa) }\end{array}$ & Catalyst & $\tau$ & $\mathbf{S} / \mathbf{F}$ & System & $\begin{array}{c}\text { Reactor } \\
\text { dimension }\end{array}$ & $\begin{array}{c}\text { Optimal } \\
\text { conditions }\end{array}$ & Ref. \\
\hline Bean dregs & $\begin{array}{l}<140 \\
\text { mesh }\end{array}$ & $220-300$ & $5.4-9.4$ & $\mathrm{CO}_{2}$ & $\begin{array}{l}2-10 \\
\min \end{array}$ & $\begin{array}{c}1 \mathrm{~g} / 200 \\
\mathrm{~mL}\end{array}$ & Batch & $\begin{array}{l}200 \mathrm{~mL} \\
\text { reactor, } \\
316 \mathrm{SS}\end{array}$ & $\begin{array}{l}\underline{\mathrm{OS} \text { and } \mathrm{MS}} \\
50 \% \text { cellulose } \\
\left(\text { without } \mathrm{CO}_{2}\right) \\
65 \% \text { cellulose } \\
\left(\text { with } \mathrm{CO}_{2}\right) \\
\left(300^{\circ} \mathrm{C}, 360 \mathrm{~s}\right)\end{array}$ & [98] \\
\hline Rice husks & n.s. & 180 & $>$ Psat & None & $\begin{array}{c}15-40 \\
\min \end{array}$ & $\begin{array}{c}1 \mathrm{~kg} / 8 \mathrm{~kg} \\
\text { water }\end{array}$ & Batch & n.s. & $\begin{array}{l}\text { OS: } \\
\begin{array}{l}\text { ON } \\
\text { xylan }(30 \\
\text { min })\end{array} \\
\text { MS: } \\
9 \% \text { xylan }(30 \mathrm{~min})\end{array}$ & [28] \\
\hline $\begin{array}{c}\text { Corn stalks } \\
\text { (pre-washe } \\
\text { d) }\end{array}$ & $\begin{array}{l}<40 \\
\text { mesh }\end{array}$ & $\begin{array}{c}384 \rightarrow \\
280\end{array}$ & > Psat & None & $16-24$ & $\begin{array}{l}40 \mathrm{mg} / \\
2.5 \mathrm{~mL} \\
\text { water }\end{array}$ & Batch & $\begin{array}{l}5 \mathrm{~mL} \text { (i.d. } 7 \\
\text { x } 2.5 \mathrm{~mm}, \\
\text { length }= \\
130 \mathrm{~mm})\end{array}$ & 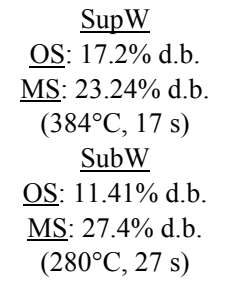 & [23] \\
\hline $\begin{array}{c}\text { Wheat } \\
\text { straw } \\
\text { (pre-washe } \\
\text { d) }\end{array}$ & $\begin{array}{l}<40 \\
\text { mesh }\end{array}$ & $\begin{array}{c}384 \rightarrow \\
280\end{array}$ & > Psat & None & $16-21$ & $\begin{array}{l}20 \mathrm{mg} / \\
2.5 \mathrm{~mL} \\
\text { water }\end{array}$ & Batch & $\begin{array}{l}5 \mathrm{~mL} \text { (i.d. } 7 \\
\text { x } 2.5 \mathrm{~mm}, \\
\text { length }= \\
130 \mathrm{~mm})\end{array}$ & 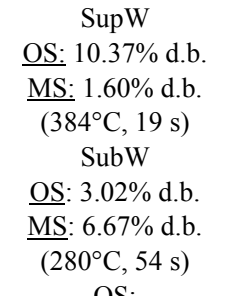 & [23] \\
\hline $\begin{array}{l}\text { Barley } \\
\text { husks }\end{array}$ & $>1 \mathrm{~mm}$ & $190-220$ & $>$ Psat & None & $\begin{array}{c}0.55-0 . \\
88 \mathrm{~h}\end{array}$ & $\begin{array}{c}1 \mathrm{~kg} / 10 \\
\mathrm{~kg} \text { water }\end{array}$ & Batch & $\begin{array}{c}3.8 \mathrm{~L} \\
316 \mathrm{SS}\end{array}$ & $\begin{array}{c}\text { OS: } \\
\text { Xylo-OS: } 18 \% \text { d.b. } \\
\text { Ara-OS: } 2.2 \% \text { d.b. } \\
\left(200^{\circ} \mathrm{C}, 0.7 \mathrm{~h}\right) \\
\text { MS: } \\
4.5 \% \text { d.b. } \\
\left(220^{\circ} \mathrm{C}, 0.7 \mathrm{~h}\right)\end{array}$ & [99] \\
\hline $\begin{array}{c}\text { Sugarcane } \\
\text { bagasse }\end{array}$ & $\begin{array}{l}>40 \\
\text { mesh }\end{array}$ & 200 & $>$ Psat & None & $\begin{array}{c}0-20 \\
\min \end{array}$ & $\begin{array}{l}0.5-10 \\
\mathrm{~g} / 100 \mathrm{~g} \\
\text { water. }\end{array}$ & Batch & $9 \mathrm{~mL}$ & $\begin{array}{c}\text { OS: } 86 \% \text { xylan } \\
\text { MS: } 13 \% \text { xylan } \\
\begin{array}{c}\text { (S/F: } 0.5, \text { t: } 10 \\
\text { min })\end{array}\end{array}$ & {$[100]$} \\
\hline $\begin{array}{c}\text { Empty fruit } \\
\text { bunches }\end{array}$ & $\begin{array}{l}>50 \\
\text { mesh }\end{array}$ & $160-180$ & $>$ Psat & & $\begin{array}{c}0-40 \\
\min \end{array}$ & $1 \mathrm{~g} / 8 \mathrm{~mL}$ & Batch & $\begin{array}{c}9 \mathrm{~mL}, \\
316 \mathrm{SS}\end{array}$ & $\begin{array}{c}\text { MS: } \\
\text { Xylose: } 18 \mathrm{~g} / \mathrm{L} \\
\left(180^{\circ} \mathrm{C}, 10 \mathrm{~min}\right) \\
\text { Glucose: } 0.8 \mathrm{~g} / \mathrm{L} \\
\left(180^{\circ} \mathrm{C}, 10 \mathrm{~min}\right)\end{array}$ & [43] \\
\hline $\begin{array}{l}\text { Eucalyptus } \\
\text { globulus } \\
\text { wood }\end{array}$ & $>8 \mathrm{~mm}$ & $180-220$ & > Psat & None & $0-1 \mathrm{~h}$ & n.s. & Batch & $\begin{array}{c}0.6 \text { and } 3.8 \\
\text { L } \\
316 \mathrm{SS}\end{array}$ & $\begin{array}{c}\text { OS: } 62 \% \text { xylan } \\
\left(212^{\circ} \mathrm{C}, 0.3 \mathrm{~h} \text { for }\right. \\
0.6 \mathrm{~L}, 0.9 \mathrm{~h} \text { for } 3.8 \\
\mathrm{~L}) \\
\underline{\mathrm{MS}}: 8 \% \text { xylan } \\
\left(212^{\circ} \mathrm{C}, 0.3 \mathrm{~h} \text { for }\right. \\
0.6 \mathrm{~L} \text { and } 0.9 \mathrm{~h} \text { for } \\
3.8 \mathrm{~L})\end{array}$ & [21] \\
\hline Corn cobs & $>0.3 \mathrm{~mm}$ & 179 & $>$ Psat & None & $23 \mathrm{~min}$ & $625 \mathrm{~g} / 5 \mathrm{~L}$ & Batch & $\begin{array}{c}10 \mathrm{~L}, \\
\text { Material: } \\
\text { ANSI } 304 \\
\text { and SS } 316\end{array}$ & $\begin{array}{c}\text { OS: } 64 \% \text { initial } \\
\text { xylan, } 11 \% \text { initial } \\
\text { cellulose } \\
\text { MS: } 9 \% \text { initial } \\
\text { xylan, } 5 \% \text { initial } \\
\text { cellulose }\end{array}$ & [41] \\
\hline $\begin{array}{c}\text { Almond } \\
\text { shell }\end{array}$ & $>300 \mu \mathrm{m}$ & 179 & $>$ Psat & None & $23 \mathrm{~min}$ & $833 \mathrm{~g} / 5 \mathrm{~L}$ & Batch & $\begin{array}{c}10 \mathrm{~L}, \\
\text { Material: } \\
\text { ANSI } 304 \\
\text { and SS } 316\end{array}$ & $\begin{array}{c}\text { OS: } 56 \% \text { initial } \\
\text { xylan, } 3 \% \text { initial } \\
\text { cellulose } \\
\text { MS: } 10 \% \text { initial } \\
\text { xylan, } 2 \% \text { initial } \\
\text { cellulose }\end{array}$ & [41] \\
\hline
\end{tabular}


Table 4. Subcritical hydrolysis of agricultural and agroindustrial residues (Cont.)

\begin{tabular}{|c|c|c|c|c|c|c|c|c|c|c|}
\hline Biomass & Size & $\begin{array}{l}\text { Temp. } \\
\left({ }^{\circ} \mathrm{C}\right)\end{array}$ & $\begin{array}{c}\text { Pressure } \\
\text { (MPa) }\end{array}$ & Catalyst & $\tau$ & $\mathbf{S} / \mathbf{F}$ & System & $\begin{array}{c}\text { Reactor } \\
\text { dimension }\end{array}$ & $\begin{array}{c}\text { Optimal } \\
\text { conditions }\end{array}$ & Ref. \\
\hline Almond shell & $\begin{array}{c}>300 \\
\mu \mathrm{m}\end{array}$ & 179 & $>$ Psat & None & $23 \mathrm{~min}$ & $833 \mathrm{~g} / 5 \mathrm{~L}$ & Batch & $\begin{array}{c}10 \mathrm{~L}, \\
\text { Material: } \\
\text { ANSI } 304 \\
\text { and SS } 316\end{array}$ & $\begin{array}{c}\text { OS: } 56 \% \text { initial } \\
\text { xylan, } \\
3 \% \text { initial } \\
\text { cellulose } \\
\text { MS: } 10 \% \text { initial } \\
\text { xylan, } 2 \% \text { initial } \\
\text { cellulose }\end{array}$ & {$[41]$} \\
\hline Rice husk & $\begin{array}{c}>300 \\
\mu \mathrm{m}\end{array}$ & 179 & $>$ Psat & None & $23 \mathrm{~min}$ & $833 \mathrm{~g} / 5 \mathrm{~L}$ & Batch & $\begin{array}{c}10 \mathrm{~L}, \\
\text { Material: } \\
\text { ANSI } 304 \\
\text { and SS } 316\end{array}$ & $\begin{array}{c}\text { OS: } 30 \% \text { initial } \\
\text { xylan } \\
12 \% \text { initial } \\
\text { cellulose } \\
\text { MS: } 6 \% \text { initial } \\
\text { xylan, } 1 \% \text { initial } \\
\text { cellulose }\end{array}$ & {$[41]$} \\
\hline $\begin{array}{c}\text { Ginger bagasse } \\
\text { after } \mathrm{CO}_{2} \\
\text { supercritical } \\
\text { extraction }\end{array}$ & n.s. & $176-200$ & 15 & $\mathrm{CO}_{2}$ & $\begin{array}{l}0-15 \\
\min \end{array}$ & $\begin{array}{l}3 \mathrm{~g} / 7 \mathrm{~g} \text { of } \\
\text { water }\end{array}$ & Batch & $5 \mathrm{~mL}$ & $\begin{array}{c}\text { OS: } \\
10000-100000 \\
\text { Da: } 30-40 \% \\
\text { hydrolyzate } \\
\left(176^{\circ} \mathrm{C}\right) \\
160-8400 \mathrm{Da}: \\
60-75 \% \\
\text { hydrolyzate } \\
\left(188^{\circ} \mathrm{C}\right) \\
\text { MS: } \\
18 \% \text { starch } \\
\left(200^{\circ} \mathrm{C}, \quad 11\right. \\
\text { min })\end{array}$ & {$[36]$} \\
\hline Beet fiber & n.s. & $160-180$ & $>$ Psat & None & $\begin{array}{l}5-15 \\
\min \end{array}$ & $\begin{array}{c}3.8 \mathrm{~g} / 35 \mathrm{~g} \\
\text { of water }\end{array}$ & Batch & $50 \mathrm{~mL}$ & $\begin{array}{c}\underline{\mathrm{OS}} \\
84 \% \text { d.b. } \\
\left(160^{\circ} \mathrm{C}, 12 \mathrm{~min}\right)\end{array}$ & [101] \\
\hline
\end{tabular}

OS: oligosaccharide, MS: monosaccharide

\subsubsection{Hydrothermal Treatment of Cellulose}

Several studies of the depolymerization of cellulose in subcritical and supercritical water have been performed at temperatures above $200^{\circ} \mathrm{C}$ and pressures above its saturated pressure, and particularly in near-critical water, with the objective of providing a suitable reaction environment for the breakdown of its glycosidic bonds, which are highly resistant to chemical attack [15], [16], [81-95]. Hydrolysis of cellulose results in oligomers with various degrees of polymerization, including insoluble oligomers (DP < 200) and soluble oligomers ( $\mathrm{DP}<6)$.

Short residence times promoted the formation of oligosaccharides [81], [92]. These oligosaccharides are further converted into a monosaccharide, glucose, which is epimerized to form fructose. Glucose is further degraded to form several compounds, such as 5-HMF, erythrose, glycolaldehyde and acidic organic compounds. Insoluble residues of cellulose with predominantly aromatic carbon structures are also formed [73], [85], [102]. The scheme of the reaction pathways is shown in Figure 6.

Moeller et al. [85] studied the effect of the degree of cellulose crystallinity (38\% to $74 \%$ crystallinity index) on its conversion and the saccharide yield at $205^{\circ} \mathrm{C}$. A high level of conversion (approximately 40\%) was obtained using cellulose with low crystallinity values $(33 \%$ and $42 \%$ crystallinity index) due to the presence of larger amorphous regions. Moreover, no effect of the crystallinity on glucose and 5-HMF formation was found.

Tolonen et al. [81] studied the degradation of cellulose using water in sub- and supercritical media $\left(280-380^{\circ} \mathrm{C}\right)$. The decrease of the dielectric constant of water as well as those of the polar solvents and the increase in the ionic product of water with values higher than those under normal conditions increased the solvation of hydrophobic compounds. The products obtained were insoluble oligosaccharides, water-soluble oligosaccharides, fructose, glucose, 5-HMF and furfural. The highest level of oligosaccharide formation (25\% oligosaccharides) was attained at the highest temperature and the shortest reaction period $\left(380^{\circ} \mathrm{C}, 0.25 \mathrm{~s}\right)$. Additionally, other researchers have reported that cellulose dissolution occurred at temperatures greater than $250^{\circ} \mathrm{C}$ [73], [91-93], [103].

A comparative study of the hydrolysis of cellulose under subcritical conditions $\left(280^{\circ} \mathrm{C}, 40 \mathrm{MPa}\right)$, supercritical conditions $\left(400^{\circ} \mathrm{C}, 40 \mathrm{MPa}\right)$, and using a combined treatment was performed to evaluate the variation in the reaction rate behaviors. Hydrolysis in supercritical media produced the highest yield of hydrolyzate compounds $(47 \%,<1 \mathrm{~min})$, the rate of formation of oligomers was higher than the rates at which monomers and fragmentation products of cellulose, such as erythrose and glycolaldehyde, were formed. Subcritical hydrolysis resulted in the lowest yield $(22.4 \%, 4$ $\mathrm{min}$ ), and the rate of formation of monomers was higher than 
the rates at which oligomers and dehydration products, such as furfural, 5-hydroxymethylfurfural and levoglucosan $(14.7 \%)$ were formed. The yield of monosaccharides in the subcritical medium was greater than that in the supercritical medium, indicating that the reaction mechanisms were different. The combined hydrolysis of cellulose using supercritical and subcritical media resulted in high yields of monosaccharides and oligosaccharides (66.8\%) and low levels of fragmentation and dehydration products, such as furfural, 5-hydroxymethylfurfural $(10.7 \%)$, erythrose and glycolaldehyde (9.7\%) [65].

The use of an integral process of supercritical hydrolysis $\left(384^{\circ} \mathrm{C}, 22 \mathrm{MPa}\right)$ followed by subcritical hydrolysis $\left(280^{\circ} \mathrm{C}\right.$, $22 \mathrm{MPa}$ ) was studied by Zhao et al. with the aim of maximizing the monosaccharide yield from the cellulose in corn stalks because the reaction rate of oligosaccharides is higher than the reaction rate of monosaccharides under supercritical conditions close to the critical point [23], [95], [102], [104], [105]. The maximum production achieved in the supercritical medium was $17.2 \%$ for oligosaccharides and $23.1 \%$ for monosaccharides in the short period of $17 \mathrm{~s}$. The subsequent treatment at $280^{\circ} \mathrm{C}$ in the subcritical medium increased the production of monosaccharides from 23.2 to $27.4 \%$. No xylose groups from hemicellulose were detected, indicating that they had been degraded in the supercritical medium.

The use of $\mathrm{CO}_{2}$ as a "green" catalyst for hydrolysis in subcritical and supercritical media has been considered due to the formation of carbonic acid, which accelerates the reaction process. Investigations using $\mathrm{CO}_{2}$ showed that the rate of monomer formation increased and the monomer yields were higher than those obtained using only water. An advantage of using $\mathrm{CO}_{2}$ is that it can be easily separated from the product and can be recycled for use in the process [72], [97], [106], [107].

\subsubsection{Hydrothermal Treatment of Hemicellulose}

Like cellulose, hemicellulose contains a fraction that is susceptible to chemical attack, which is responsible for the formation of hydrolyzed products. The hydrolysis of hemicellulose using hydrolytic processes produces xylooligosaccharides with various structures and compositions. The variability depends primarily on the hemicellulose source and the hydrolytic process used. Hydrothermal treatment at temperatures of approximately $200^{\circ} \mathrm{C}$ produces a slightly acidic medium due to the partial cleavage of the acetyl groups of hemicellulose, yielding xylooligosaccharides of high molecular weight with a significant content of acetyl and uronic groups, which confer high solubility in water. Additionally, there is a partial depolymerization of cellulose and lignin, which can be separated for subsequent processing [108], [109]. In general, hemicellulose is hydrolyzed into high molecular weight oligomers, low molecular weight oligomer, xylose, furfural and degradation products, as shown in Figure 7 [96], [97].

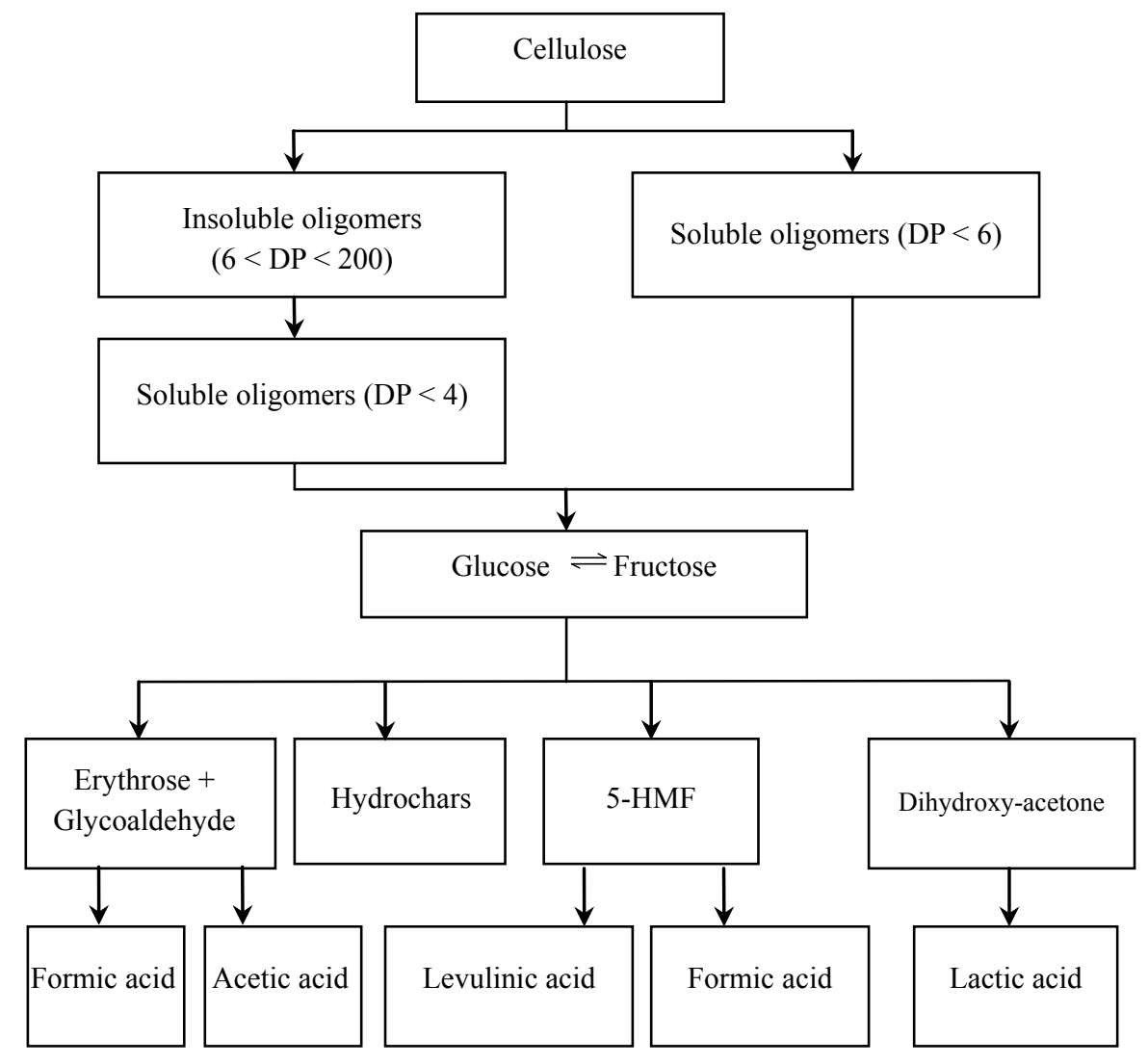

Figure 6. Main reaction pathways of cellulose hydrolysis (adapted from [73], [85], [102]) 


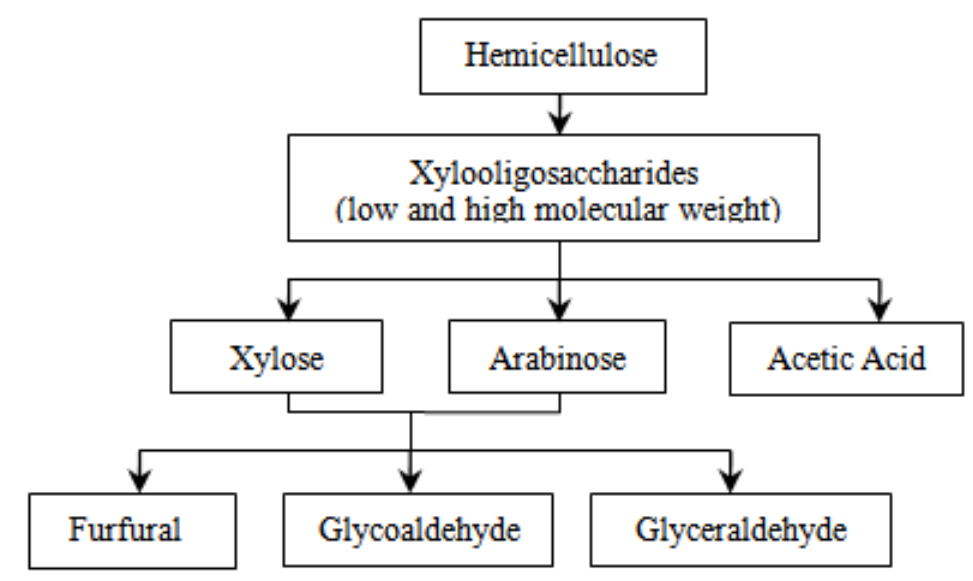

Figure 7. Main reaction pathway of hemicellulose hydrolysis (adapted from [96])

Nabarlatz et. al. [41] studied the hemicellulose hydrolysis of six different lignocellulosic materials: corn cob, almond shell, olive stone, rice husk, wheat straw and barley straw and they found that xylooligomers formed were mainly 4-O-methylgucuronoxylan with different degrees of substitution of acetyl groups. Additionally, each raw material presented different yield of xylooligosaccharides and it was proportional with the quantity of acetic acid formed from acetyl groups and initial xylan content resulting in highest yield for corn cob (60\% initial xylan) and lowest yield for rice husk ( $30 \%$ initial xylan) due to its lowest acetyl content. It was found that substrate with high lignin content as olive stone and almond shell resulted in low formation of oligossacharides from cellulose and polymerization of lignin. So, substrates with high lignin content and high acetyl groups in hemicelluloses lead on highest yield of xylooligosaccharides.

Garrote et. al. [99] studied the autohydrolysis of hemicellulose in barley husks at a temperature range between 190 and $220^{\circ} \mathrm{C}$. The breakdown of hemicelluloses chains conducted at temperatures up to $200^{\circ} \mathrm{C}$ resulted on the highest concentrations of xylooligosaccharides $(18 \%$ d.b.) and arabinosaccharides $(2.2 \%$ d.b.), and the cleavage of substituents such as acetyl groups and uronic acid groups. The dissolution of these groups promoted an increment of hydrogen ions which led the hydrolytic degradation of polymer chains into oligosaccharide (xylo- and arabinooligosaccharides), monosaccharides (xylose, arabinose and glucose), furfural and non-saccharides compounds. The maximum concentration of xylose and arabinose were $3 \%$ d.b. and $2.2 \%$ d.b, respectively at $220^{\circ} \mathrm{C}$. These results showed that temperatures up to $200^{\circ} \mathrm{C}$ favored the formation of oligosaccharides. Furthermore, the amount of degradation products of furfural, and non-saccharide compounds comprised $18 \%$ d.b. Among these non-saccharides compounds, hexanoic acid, octadecanoic acid, oleic acid, tetradecanoic acid and dehydroabietic acid were identified and they can be used as surfactants in cosmetics. Additionally, phenolic compounds such as vanillin, 3,4-dihydroxybenzaldehyde, 3-methoxy-4hydroxybenzoic acid, and cinnamic acid can be used as food antioxidants. A purification of these non-saccharide compounds can increase the food grade of the oligosaccharides.

Jacobsen et al. [100] studied the dissolution of the hemicelluloses to $200^{\circ} \mathrm{C}$ and various $\mathrm{S} / \mathrm{F}$ ratios from 0.5 to 10 in a batch system of $9 \mathrm{~mL}$. It was generally observed that the initial $\mathrm{pH}$ decreased from 7 to 4.5 , and continuously decreased with increasing reaction time. Additionally, high $\mathrm{pH}$ values were obtained at high ratios of $\mathrm{S} / \mathrm{F}$ due to the increment in amount of acetic acids and uronic acids which promotes the reaction rate of hemicellulose hydrolysis. As obtained in other researches at this temperature, hydrolysate products consisted mainly of oligosaccharides and monosaccharides, being oligosaccharides concentration higher than monosaccharides concentration. Additionally, the lowest $\mathrm{S} / \mathrm{F}$ ratio of 0.5 resulted in highest concentration of total sugars ( $86 \%$ of initial xylan) compared to $\mathrm{S} / \mathrm{F}$ ratio of $10(75 \%$ of initial xylan) showing that not only the effect of $\mathrm{pH}$ affects hydrolytic dissolution of the hemicellulose.

The non-isothermal hydrolysis of hemicellulose fraction of wood chips from 180 to $220^{\circ} \mathrm{C}$ in two reactors of 0.6 and $3.8 \mathrm{~L}$ showed a maximum yield of xylooligosaccharides $\left(62 \%\right.$ of initial xylan) at $212^{\circ} \mathrm{C}$. Additionally, there was a continuous increment of xylose concentration with reaction time. Furthermore, saccharides yield presented similar behavior for both reactor capacities as its kinetic constants were close for both processes. In addition, there was a negligible depolymerization of cellulose and lignin showing selectivity for hemicellulose hydrolysis [21].

Vegas et al. [28] have studied the subcritical hydrolysis of rice husks at $180^{\circ} \mathrm{C}$ and different residence times using severity coefficient (3.5-4.0) as a measurement of treatment. It was observed an initial formation and further decomposition of xylooligosaccharides during reaction course. The maximum xylooligosaccharide concentration was obtained with severity coefficient (Ro) of 3.9. Relating to the xylose constituents, arabinosyl and acetyl substituents were less resistant than uronic substituent due to hydrolytic cleavage. Additionally, it was found that oligomers with DP $<25$ constituted $90-94 \%$ of total xylooligosaccharides even at low severities. 


\subsubsection{Hydrothermal Treatment of Starch}

Few applications of subcritical hydrolysis of starch have been founded in literature. From the obtained information, the main products of starch hydrolysis in subcritical medium are maltodextrins, dextrins and glucose; which have application in cosmetics, pharmaceutical and food industry. The subcritical hydrolysis of ginger bagasse at $200^{\circ} \mathrm{C}$ and 15 MPa resulted in highest degree of hydrolysis of $97.1 \%$ at a time of $15 \mathrm{~min}$ and the highest yield of reducing sugars of $18.1 \%$ at a time of 11 minutes. Different mixtures of oligosaccharides with different molecular weight distribution were obtained depending on reaction time [36]. Another application is the subcritical hydrolysis of potato starch and cassava starch for production of indigestible dextrin (ID). The highest ID for potato starch was obtained at $190^{\circ} \mathrm{C}$ and $2 \mathrm{~min}(14 \%)$, and highest ID for cassava starch was obtained at $200 \mathrm{C}$ and $2 \mathrm{~min}(6 \%)$ [110].

\section{Conclusions}

Hydrothermal treatment of agricultural and agricultural residues produces value-added products that have numerous applications, either as intermediates for chemical industry or as raw materials for food, cosmetic and pharmaceutical industry. One of the most interesting applications in the food industry is the formation of oligosaccharides that can be used as dietary fiber in food products or monosaccharides that can then be transformed into polyols. The conversion of cellulose, hemicellulose and starch using water in subcritical and supercritical states takes advantage of the changing properties of water at temperatures and pressures above normal conditions. Thus, depending on the polysaccharide type certain conditions promote highest oligosaccharides and monosaccharides formation. Based on hydrolysis studies of model compounds and lignocellulosic materials, starch and hemicellulose components are preferred to be converted at temperature less than $200^{\circ} \mathrm{C}$, while cellulose is most suitable to be converted at temperature higher than $200^{\circ} \mathrm{C}$ for recovery of oligosaccharides and monosaccharides.

\section{ACKNOWLEDGEMENTS}

The authors acknowledge the financial support of DEA/FEA/PROEX, CNPq (560914/2010-5) and FAPESP (2011/19817-1 and 2012/10685-8); F. P. Cardenas-Toro is grateful to CAPES-PEC-PG (5945100) for the Ph.D. assistantship; and M. A. A. Meireles is grateful to CNPq for the productivity grant (301301/2010-7).

\section{REFERENCES}

[1] K. Edwin, Biofuels, climate change, and human population, in Global Economic and Environmental Aspects of Biofuels, CRC Press, 2012.
[2] F. Cherubini, "The biorefinery concept: Using biomass instead of oil for producing energy and chemicals", Energy Conversion and Management, vol.51, no.7, pp.1412-1421, 2010.

[3] R. Gupta, Demirbas, A., Renewable Energy Sources, in Gasoline, Diesel, and Ethanol Biofuels from Grasses and Plants, First Editionn ed., 2010.

[4] D. Dhingra, M. Michael, H. Rajput, R. T. Patil, "Dietary fibre in foods: a review", Journal of Food Science and Technology, vol.49, no.3, pp.255-266, 2012.

[5] D. Klemm, B. Philipp, T. Heinze, U. Heinze, W. Wagenknecht, General Considerations on Structure and Reactivity of Cellulose: Section 2.1-2.1.4, in Comprehensive Cellulose Chemistry, Wiley-VCH Verlag GmbH \& Co. KGaA, 2004.

[6] M. C. McCann, N. C. Carpita, "Designing the deconstruction of plant cell walls", Current Opinion in Plant Biology, vol.11, no.3, pp.314-320, 2008.

[7] R. F. Evert, Cell Wall, in Esau's Plant Anatomy, John Wiley \& Sons, Inc., 2006.

[8] J. C. Thimm, D. J. Burritt, W. A. Ducker, L. D. Melton, "Celery (Apium graveolens L.) parenchyma cell walls examined by atomic force microscopy: effect of dehydration on cellulose microfibrils",NLM, Planta, vol.212, no.1, pp.25-32, 2000.

[9] Y. Nishiyama, "Structure and properties of the cellulose microfibril", Journal of Wood Science, vol.55, no.4, pp.241-249, 2009.

[10] M. E. Himmel, S. Y. Ding, D. K. Johnson, W. S. Adney, M. R. Nimlos, J. W. Brady, T. D. Foust, "Biomass recalcitrance: engineering plants and enzymes for biofuels production", NLM, Science (New York, N.Y.), vol.315, no.5813, pp.804-807, 2007.

[11] R. L. David, The Chemistry of Complex Carbohydrates, in Complex Carbohydrates in Foods, CRC Press, 1999.

[12] P. Harmsen, W. Huijgen, L. Bermudez, R. Bakker, "Literature review of physical and chemical pretreatment processes for lignocellulosic biomass", Wageningen UR, Food \& Biobased Research, 2010.

[13] H. V. Scheller, P. Ulvskov, "Hemicelluloses",NLM, Annual review of plant biology, vol.61, pp.263-289, 2010.

[14] M. Borrega, K. Nieminen, H. Sixta, "Degradation kinetics of the main carbohydrates in birch wood during hot water extraction in a batch reactor at elevated temperatures", Bioresource Technology, vol.102, no.22, pp.10724-10732, 2011.

[15] Y. Kim, T. Kreke, N. S. Mosier, M. R. Ladisch, "Severity Factor Coefficients for Subcritical Liquid Hot Water Pretreatment of Hardwood Chips", Biotechnology and Bioengineering, vol.111, no.2, pp.254-263, 2014.

[16] X. Lu, S. Saka, "Hydrolysis of Japanese beech by batch and semi-flow water under subcritical temperatures and pressures", Biomass \& Bioenergy, vol.34, no.8, pp.1089-1097, 2010.

[17] M. Matsunaga, H. Matsui, Y. Otsuka, S. Yamamoto, "Chemical conversion of wood by treatment in a semi-batch reactor with subcritical water", Journal of Supercritical Fluids, 
vol.44, no.3, pp.364-369, 2008

[18] M. Carrier, A. Loppinet-Serani, C. Absalon, C. Aymonier, M. Mench, "Degradation pathways of holocellulose, lignin and alpha-cellulose from Pteris vittata fronds in sub- and super critical conditions", Biomass \& Bioenergy, vol.43, pp.65-71, 2012.

[19] L. Cheng, X. P. Ye, R. He, S. Liu, "Investigation of rapid conversion of switchgrass in subcritical water", Fuel Processing Technology, vol.90, no.2, pp.301-311, 2009.

[20] K. Tekin, S. Karagoz, S. Bektas, "Hydrothermal liquefaction of beech wood using a natural calcium borate mineral", Journal of Supercritical Fluids, vol.72, pp.134-139, 2012.

[21] G. Garrote, J. C. Parajó, "Non-isothermal autohydrolysis of Eucalyptus wood", Wood Science and Technology, vol.36, no.2, pp.111-123, 2002.

[22] H. Pinkowska, "Low-temperature biomass gasification in subcritical and supercritical water", Przemysl Chemiczny, vol.86, no.7, pp.599-606, 2007.

[23] Y. Zhao, W.J. Lu, H.T. Wang, J.L. Yang, "Fermentable hexose production from corn stalks and wheat straw with combined supercritical and subcritical hydrothermal technology", Bioresource Technology, vol.100, no.23, pp.5884-5889, 2009.

[24] C. C. Song, H. Q. Hu, S. W. Zhu, G. Wang, G. H. Chen, "Nonisothermal catalytic liquefaction of corn stalk in subcritical and supercritical water", Energy \& Fuels, vol.18, no.1, pp.90-96, 2004.

[25] C. Sanchez, I. Eguees, A. Garcia, R. Llano-Ponte, J. Labidi, "Lactic acid production by alkaline hydrothermal treatment of corn cobs", Chemical Engineering Journal, vol.181, pp.655-660, 2012.

[26] G. Garrote, E. Falque, H. Dominguez, J. C. Parajo, "Autohydrolysis of agricultural residues: study of reaction byproducts",NLM, Bioresour Technol, vol.98, no.10, pp.1951-1957, 2007.

[27] S. Kumar, U. Kothari, L. Kong, Y. Y. Lee, R. B. Gupta, "Hydrothermal pretreatment of switchgrass and corn stover for production of ethanol and carbon microspheres", Biomass \& Bioenergy, vol.35, no.2, pp.956-968, 2011.

[28] R. Vegas, M. Kabel, H. A. Schols, J. L. Alonso, J. C. Parajó, "Hydrothermal processing of rice husks: effects of severity on product distribution", Journal of Chemical Technology \& Biotechnology, vol.83, no.7, pp.965-972, 2008.

[29] L. Kong, G. Li, H. Wang, W. He, F. Ling, "Hydrothermal catalytic conversion of biomass for lactic acid production", Journal of Chemical Technology and Biotechnology, vol.83, no.3, pp.383-388, 2008.

[30] S. Hata, J. Wiboonsirikul, A. Maeda, Y. Kimura, S. Adachi, "Extraction of defatted rice bran by subcritical water treatment", Biochemical Engineering Journal, vol.40, no.1, pp.44-53, 2008.

[31] T. Ingram, T. Rogalinski, V. Bockemühl, G. Antranikian, G. Brunner, "Semi-continuous liquid hot water pretreatment of rye straw", The Journal of Supercritical Fluids, vol.48, no.3, pp.238-246, 2009.

[32] R. Singh, T. Bhaskar, S. Dora, B. Balagurumurthy, "Catalytic hydrothermal upgradation of wheat husk", Bioresource
Technology, vol.149, pp.446-451, 2013.

[33] B. A. Cinelli, J. A. López, L. R. Castilho, D. M. G. Freire, A. M. Castro, "Granular starch hydrolysis of babassu agroindustrial residue: A bioprocess within the context of biorefinery", Fuel, vol.124, no.0, pp.41-48, 2014.

[34] M. Sasaki, T. Adschiri, K. Arai, "Fractionation of sugarcane bagasse by hydrothermal treatment",NLM, Bioresource Technology, vol.86, no.3, pp.301-304, 2003.

[35] G. e. Luo, W. Shi, X. Chen, W. Ni, P. J. Strong, Y. Jia, H. Wang, "Hydrothermal conversion of water lettuce biomass at 473 or $523 \mathrm{~K}$ ", Biomass \& Bioenergy, vol.35, no.12, pp.4855-4861, 2011.

[36] S. R. M. Moreschi, A. J. Petenate, M. A. A. Meireles, "Hydrolysis of ginger bagasse starch in subcritical water and carbon dioxide", Journal of Agricultural and Food Chemistry, vol.52, no.6, pp.1753-1758, 2004.

[37] M. Tanaka, A. Takamizu, M. Hoshino, M. Sasaki, M. Goto, "Extraction of dietary fiber from Citrus junos peel with subcritical water", Food and Bioproducts Processing, vol.90, no.C2, pp.180-186, 2012.

[38] W. Daengprasert, P. Boonnoun, N. Laosiripojana, M. Goto, A. Shotipruk, "Application of Sulfonated Carbon-Based Catalyst for Solvothermal Conversion of Cassava Waste to Hydroxymethylfurfural and Furfural", Industrial \& Engineering Chemistry Research, vol.50, no.13, pp.7903-7910, 2011.

[39] E. Hermiati, J.-i. Azuma, S. Tsubaki, D. Mangunwidjaja, T. C. Sunarti, O. Suparno, B. Prasetya, "Improvement of microwave-assisted hydrolysis of cassava pulp and tapioca flour by addition of activated carbon", Carbohydrate Polymers, vol.87, no.1, pp.939-942, 2012.

[40] E. Coelho, M. A. Rocha, J. A. Saraiva, M. A. Coimbra, "Microwave superheated water and dilute alkali extraction of brewers' spent grain arabinoxylans and arabinoxylooligosaccharides", NLM, Carbohydrate Polymers, vol.99, pp.415-422, 2014.

[41] D. Nabarlatz, A. Ebringerová, D. Montané, "Autohydrolysis of agricultural by-products for the production of xylo-oligosaccharides", Carbohydrate Polymers, vol.69, no.1, pp.20-28, 2007.

[42] S. Sabiha-Hanim, M. A. Noor, A. Rosma, "Effect of autohydrolysis and enzymatic treatment on oil palm (Elaeis guineensis Jacq.) frond fibres for xylose and xylooligosaccharides production",NLM, Bioresource Technology, vol.102, no.2, pp.1234-1239, 2011.

[43] J. S. Kim, W. I. Choi, M. Kang, J. Y. Park, J. S. Lee, "Kinetic study of empty fruit bunch using hot liquid water and dilute acid",NLM, Applied Biochemistry and Biotechnology, vol.167, no.6, pp.1527-1539, 2012.

[44] H. Mazaheri, K. T. Lee, A. R. Mohamed, "Influence of temperature on liquid products yield of oil palm shell via subcritical water liquefaction in the presence of alkali catalyst", Fuel Processing Technology, vol.110, pp.197-205, 2013.

[45] F. P. Cardenas-Toro, T. Forster-Carneiro, M. A. Rostagno, A. J. Petenate, F. Maugeri Filho, M. A. A. Meireles, "Integrated supercritical fluid extraction and subcritical water hydrolysis for the recovery of bioactive compounds from pressed palm 
fiber", The Journal of Supercritical Fluids, In Press, 2014.

[46] L. P. Ramos, "The chemistry involved in the steam treatment of lignocellulosic materials", Química Nova, vol.26, pp.863-871, 2003.

[47] W. Vermerris, Composytion and Biosynthesis of Lignocellulosic Biomass, in Genetic Improvement of Bioenergy Crops, W. Vermerris. Springer Science+Business Media, Florida, 2008.

[48] A. F. A. Carvalho, P. d. O. Neto, D. F. da Silva, G. M. Pastore, "Xylo-oligosaccharides from lignocellulosic materials: Chemical structure, health benefits and production by chemical and enzymatic hydrolysis", Food Research International, vol.51, no.1, pp.75-85, 2013.

[49] D. R. Lu, C. M. Xiao, S. J. Xu, "Starch-based completely biodegradable polymer materials", Express Polymer Letters, vol.3, no.6, pp.366-375, 2009.

[50] H. I. Syed, F. W. Delilah, A. A. Mohamed, C. Bor-Sen, G. W. Tina, M. G. Gregory, J. O. William, Starch, in Starch-Based Polymeric Materials and Nanocomposites, CRC Press, 2012.

[51] H. N. Englyst, S. M. Kingman, J. H. Cummings, "Classification and measurement of nutritionally important starch fractions",NLM, European Journal of Clinical Nutrition, vol.46 Suppl 2, pp.S33-50, 1992.

[52] M. Sajilata, R. S. Singhal, P. R. Kulkarni, "Resistant starch-a review", Comprehensive Reviews in Food Science and Food Safety, vol.5, no.1, pp.1-17, 2006.

[53] S. I. Shin, H. J. Kim, H. J. Ha, S. H. Lee, T. W. Moon, "Effect of Hydrothermal Treatment on Formation and Structural Characteristics of Slowly Digestible Non-pasted Granular Sweet Potato Starch", Starch - Stärke, vol.57, no.9, pp.421-430, 2005.

[54] T. L. Wang, T. Y. Bogracheva, C. L. Hedley, "Starch: as simple as A, B, C?", Journal of Experimental Botany, vol.49, no.320, pp.481-502, 1998.

[55] J. Jay-lin, Starch, in Chemical and Functional Properties of Food Saccharides, CRC Press, 2003.

[56] A. Buléon, P. Colonna, V. Planchot, S. Ball, "Starch granules: structure and biosynthesis", International Journal of Biological Macromolecules, vol.23, no.2, pp.85-112, 1998.

[57] J. K. Charles, F. K. John, Starch, in Polysaccharides, CRC Press, 2004.

[58] J. N. BeMiller, R. L. Whistler, Starch: chemistry and technology, Academic Press, 2009.

[59] T. Hajime, Carbohydrate Active Enzymes for the Production of Oligosaccharides, in Handbook of Industrial Biocatalysis, CRC Press, 2005.

[60] A. Eisentraut, Sustainable Production of Second-Generation Biofuels, OECD Publishing, 2010.

[61] V. Ferreira-Leitao, L. M. F. Gottschalk, M. A. Ferrara, A. L. Nepomuceno, H. B. C. Molinari, E. P. Bon, "Biomass residues in Brazil: availability and potential uses", Waste and Biomass Valorization, vol.1, no.1, pp.65-76, 2010.

[62] L. F. de França, M. A. A. Meireles, "Modeling the extraction of carotene and lipids from pressed palm oil (Elaes guineensis) fibers using supercritical CO2", The Journal of Supercritical
Fluids, vol.18, no.1, pp.35-47, 2000.

[63] P. F. Leal, M. B. Kfouri, F. C. Alexandre, F. H. R. Fagundes, J M. Prado, M. H. Toyama, M. A. A. Meireles, "Brazilian Ginseng extraction via LPSE and SFE: Global yields, extraction kinetics, chemical composition and antioxidant activity", The Journal of Supercritical Fluids, vol.54, no.1, pp.38-45, 2010.

[64] P. Binod, K. Janu, R. Sindhu, A. Pandey, "Hydrolysis of lignocellulosic biomass for bioethanol production", Biofuels: alternative feedstocks and conversion processes, pp.229-250, 2011.

[65] P. McKendry, "Energy production from biomass (part 2): conversion technologies", Bioresource Technology, vol.83, no.1, pp.47-54, 2002.

[66] A. Demirbaş, "Biomass resource facilities and biomass conversion processing for fuels and chemicals", Energy conversion and Management, vol.42, no.11, pp.1357-1378, 2001.

[67] A. Demirbaș, "Mechanisms of liquefaction and pyrolysis reactions of biomass", Energy Conversion and Management, vol.41, no.6, pp.633-646, 2000.

[68] J. C. Serrano-Ruiz, R. Luque, A. Sepúlveda-Escribano, "Transformations of biomass-derived platform molecules: from high added-value chemicals to fuels via aqueous-phase processing", Chemical Society Reviews, vol.40, no.11, pp.5266-5281, 2011.

[69] T. Rogalinski, K. Liu, T. Albrecht, G. Brunner, "Hydrolysis kinetics of biopolymers in subcritical water", The Journal of Supercritical Fluids, vol.46, no.3, pp.335-341, 2008.

[70] G. Garrote, H. Dominguez, J. Parajo, "Hydrothermal processing of lignocellulosic materials", European Journal of Wood and Wood Products, vol.57, no.3, pp.191-202, 1999.

[71] F. Jin, Y. Wang, X. Zeng, Z. Shen, G. Yao, Water Under High Temperature and Pressure Conditions and Its Applications to Develop Green Technologies for Biomass Conversion, in Application of Hydrothermal Reactions to Biomass Conversion, F. Jin. Springer Berlin Heidelberg, 2014.

[72] C. Schacht, C. Zetzl, G. Brunner, "From plant materials to ethanol by means of supercritical fluid technology", The Journal of Supercritical Fluids, vol.46, no.3, pp.299-321, 2008 .

[73] K. Ehara, S. Saka, "Decomposition behavior of cellulose in supercritical water, subcritical water, and their combined treatments", Journal of Wood Science, vol.51, no.2, pp.148-153, 2005.

[74] S. Ewanick, R. Bura, "Hydrothermal pretreatment of lignocellulosic biomass", Bioalcoholproduction, vol.pp.1, 2010 .

[75] J.W. King, R.D. Grabiel. "Isolation of phenolic compounds from fruits or vegetables utilizing sub-critical water extraction”, U.S. Patent 7208 181, 2007.

[76] W. Haynes, CRC Handbook of Chemistry and Physics, 94th Edition (CRC Handbook of Chemistry \& Physics), CRC Press, 2013.

[77] P. E. Savage, "A perspective on catalysis in sub- and supercritical water", The Journal of Supercritical Fluids, vol.47, no.3, pp.407-414, 2009. 
[78] A. Kruse, P. Maniam, F. Spieler, "Influence of proteins on the hydrothermal gasification and liquefaction of biomass. 2 . Model compounds", Industrial \& Engineering Chemistry Research, vol.46, no.1, pp.87-96, 2007.

[79] A. V. Bandura, S. N. Lvov, "The ionization constant of water over wide ranges of temperature and density", Journal of Physical and Chemical Reference Data, vol.35, no.1, pp.15-30, 2005 .

[80] D. P. Fernández, Y. Mulev, A. Goodwin, J. L. Sengers, "A database for the static dielectric constant of water and steam", Journal of Physical and Chemical Reference Data, vol.24, no.1, pp.33-70, 1995.

[81] L. K. Tolonen, P. A. Penttila, R. Serimaa, A. Kruse, H. Sixta, "The swelling and dissolution of cellulose crystallites in subcritical and supercritical water", Cellulose, vol.20, no.6, pp.2731-2744, 2013.

[82] Y. Yu, H. Wu, "Understanding the Primary Liquid Products of Cellulose Hydrolysis in Hot-Compressed Water at Various Reaction Temperatures", Energy \& Fuels, vol.24, pp.1963-1971, 2010

[83] H. Pinkowska, P. Wolak, "Hydrothermal decomposition of rapeseed straw in subcritical water. Proposal of three-step treatment", Fuel, vol.113, pp.340-346, 2013.

[84] H. Pinkowska, P. Wolak, E. Oliveros, "Production of xylose and glucose from rapeseed straw in subcritical water - Use of Doehlert design for optimizing the reaction conditions", Biomass \& Bioenergy, vol.58, pp.188-197, 2013.

[85] M. Moeller, F. Harnisch, U. Schroeder, "Hydrothermal liquefaction of cellulose in subcritical water-the role of crystallinity on the cellulose reactivity", Rsc Advances, vol.3, no.27, pp.11035-11044, 2013.

[86] Y. Wang, J. Wan, Y. Ma, M. Huang, "Hydrolysis kinetics characteristic of recycled fiber in subcritical water", Bioresource Technology, vol.105, pp.152-159, 2012.

[87] H. Ramsurn, R. B. Gupta, "Production of Biocrude from Biomass by Acidic Subcritical Water Followed by Alkaline Supercritical Water Two-Step Liquefaction", Energy \& Fuels, vol.26, no.4, pp.2365-2375, 2012.

[88] K. Nakahara, N. Kageyama, K. Nagami, "Enrichment of Vanillin in Barley Malt by Hydrolysis in High Temperature and High Pressure Steam", Journal of Agricultural and Food Chemistry, vol.60, no.50, pp.12384-12387, 2012.

[89] X. Lu, S. Saka, "New insights on monosaccharides' isomerization, dehydration and fragmentation in hot-compressed water", The Journal of Supercritical Fluids, vol.61, pp.146-156, 2012.

[90] M. Herrero, M. Castro-Puyana, L. Rocamora-Reverte, J. A. Ferragut, A. Cifuentes, E. Ibanez, "Formation and relevance of 5-hydroxymethylfurfural in bioactive subcritical water extracts from olive leaves", Food Research International, vol.47, no.1, pp.31-37, 2012.

[91] Y. Yu, H. Wu, "Characteristics and Precipitation of Glucose Oligomers in the Fresh Liquid Products Obtained from the Hydrolysis of Cellulose in Hot-Compressed Water", Industrial \& Engineering Chemistry Research, vol.48, no.23, pp.10682-10690, 2009.

[92] M. Sasaki, Z. Fang, Y. Fukushima, T. Adschiri, K. Arai,
"Dissolution and hydrolysis of cellulose in subcritical and supercritical water", Industrial \& Engineering Chemistry Research, vol.39, no.8, pp.2883-2890, 2000.

[93] T. Adschiri, S. Hirose, R. Malaluan, K. Arai, "Noncatalytic conversion of cellulose in supercritical and subcritical water", Journal of Chemical Engineering of Japan, vol.26, no.6, pp.676-680, 1993.

[94] Y. Yu, Z. M. Shafie, H. Wu, "Cellobiose Decomposition in Hot-Compressed Water: Importance of Isomerization Reactions", Industrial \& Engineering Chemistry Research, vol.52, no.47, pp.17006-17014, 2013.

[95] Y. Zhao, W.-J. Lu, H.-T. Wang, D. Li, "Combined Supercritical and Subcritical Process for Cellulose Hydrolysis to Fermentable Hexoses", Environmental Science \& Technology, vol.43, no.5, pp.1565-1570, 2009.

[96] H. Pinkowska, P. Wolak, A. Zlocinska, "Hydrothermal decomposition of xylan as a model substance for plant biomass waste - Hydrothermolysis in subcritical water", Biomass \& Bioenergy, vol.35, no.9, pp.3902-3912, 2011.

[97] T. Miyazawa, T. Funazukuri, "Polysaccharide Hydrolysis Accelerated by Adding Carbon Dioxide under Hydrothermal Conditions", Biotechnology Progress, vol.21, no.6, pp.1782-1785, 2005.

[98] G. Zhu, X. Zhu, Q. Fan, X. Wan, "Production of reducing sugars from bean dregs waste by hydrolysis in subcritical water", Journal of Analytical and Applied Pyrolysis, vol.90, no.2, pp.182-186, 2011.

[99] G. Garrote, H. Domínguez, J. C. Parajó, "Production of Substituted Oligosaccharides by Hydrolytic Processing of Barley Husks", Industrial \& Engineering Chemistry Research, vol.43, no.7, pp.1608-1614, 2004.

[100] S. E. Jacobsen, C. E. Wyman, "Xylose Monomer and Oligomer Yields for Uncatalyzed Hydrolysis of Sugarcane Bagasse Hemicellulose at Varying Solids Concentration", Industrial \& Engineering Chemistry Research, vol.41, no.6, pp.1454-1461, 2002.

[101] N. Sato, Y. Takano, M. Mizuno, K. Nozaki, S. Umemura, T. Matsuzawa, Y. Amano, S. Makishima, "Production of feruloylated arabino-oligosaccharides (FA-AOs) from beet fiber by hydrothermal treatment", The Journal of Supercritical Fluids, vol.79, no.0, pp.84-91, 2013.

[102] M. Sasaki, B. Kabyemela, R. Malaluan, S. Hirose, N. Takeda, T. Adschiri, K. Arai, "Cellulose hydrolysis in subcritical and supercritical water", The Journal of Supercritical Fluids, vol.13, no.1-3, pp.261-268, 1998.

[103] M. Sasaki, T. Adschiri, K. Arai, "Kinetics of cellulose conversion at $25 \mathrm{MPa}$ in sub- and Supercritical water", American Institute of Chemical Engineers Journal, vol.50, no.1, pp.192-202, 2004.

[104] Y. Zhao, W.-J. Lu, H.-T. Wang, "Supercritical hydrolysis of cellulose for oligosaccharide production in combined technology", Chemical Engineering Journal, vol.150, no.2-3, pp.411-417, 2009.

[105] D. A. Cantero, M. D. Bermejo, M. J. Cocero, "Kinetic analysis of cellulose depolymerization reactions in near critical water", The Journal of Supercritical Fluids, vol.75, pp.48-57, 2013. 
[106] T. Rogalinski, T. Ingram, G. Brunner, "Hydrolysis of lignocellulosic biomass in water under elevated temperatures and pressures", The Journal of Supercritical Fluids, vol.47, no.1, pp.54-63, 2008.

[107] J. W. King, K. Srinivas, O. Guevara, Y.-W. Lu, D. Zhang, Y.-J. Wang, "Reactive high pressure carbonated water pretreatment prior to enzymatic saccharification of biomass substrates", The Journal of Supercritical Fluids, vol.66, pp.221-231, 2012.

[108] D. Nabarlatz, X. Farriol, D. Montané, "Kinetic Modeling of the Autohydrolysis of Lignocellulosic Biomass for the Production of Hemicellulose-Derived Oligosaccharides",
Industrial \& Engineering Chemistry Research, vol.43, no.15, pp.4124-4131, 2004.

[109] D. Nabarlatz, X. Farriol, D. Montané, "Autohydrolysis of Almond Shells for the Production of Xylo-oligosaccharides: Product Characteristics and Reaction Kinetics", Industrial \& Engineering Chemistry Research, vol.44, no.20, pp.7746-7755, 2005.

[110] J. Ishii, H. Saito, K. Fujie, H. Daimon, "Hydrolysis of Starch Processing Residues in Subcritical Water Optimal Conditions for Production of Valuable Materials", Proc. 10th International Symposium on Supercritical Fluid, San Francisco, USA. 2012. 